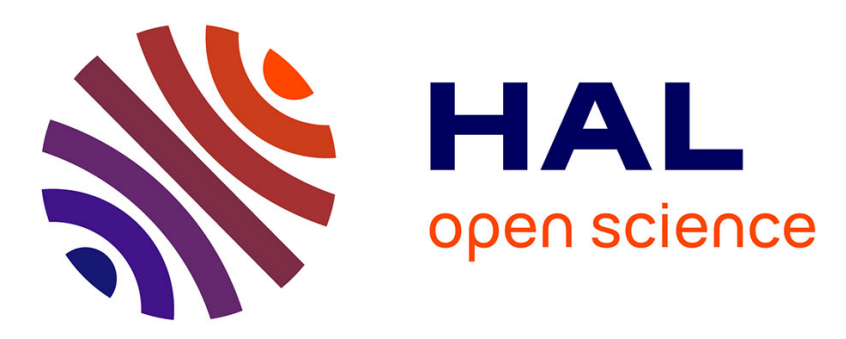

\title{
Crustal structure of the Mid-Atlantic Ridge south of the Kane Fracture Zone from seafloor and sea surface gravity data
}

Va16rie Ballu, Jacques Dubois, Christine Deplus, Michel Diament, Sylvain Bonvalot

\section{To cite this version:}

Va16rie Ballu, Jacques Dubois, Christine Deplus, Michel Diament, Sylvain Bonvalot. Crustal structure of the Mid-Atlantic Ridge south of the Kane Fracture Zone from seafloor and sea surface gravity data. Journal of Geophysical Research : Solid Earth, 1997, 103 (B2), 10.1029/97JB02542 . insu-01353976

\section{HAL Id: insu-01353976 https://hal-insu.archives-ouvertes.fr/insu-01353976}

Submitted on 16 Aug 2016

HAL is a multi-disciplinary open access archive for the deposit and dissemination of scientific research documents, whether they are published or not. The documents may come from teaching and research institutions in France or abroad, or from public or private research centers.
L'archive ouverte pluridisciplinaire HAL, est destinée au dépôt et à la diffusion de documents scientifiques de niveau recherche, publiés ou non, émanant des établissements d'enseignement et de recherche français ou étrangers, des laboratoires publics ou privés. 


\title{
Crustal structure of the Mid-Atlantic Ridge south of the Kane Fracture Zone from seafloor and sea surface gravity data
}

\author{
Valérie Ballu,' Jacques Dubois, Christine Deplus, ${ }^{2}$ Michel Diament, \\ and Sylvain Bonvalot ${ }^{3}$ \\ Laboratoire de Gravimétrie et Géodynamique, Institut de Physique du Globe de Paris
}

\begin{abstract}
Seafloor and sea surface gravity data are inverted together to construct a model for the near-axis crustal structure of a slow spreading ridge. The seafloor data set offers two main advantages: it allows us to recover shorter-wavelengths signal and to constrain the value of a potential field at two different levels. The model we propose here would not have been derived from sea surface data alone. It is based on a dense sea surface gravity coverage and on 121 sea bottom gravity measurements collected in the MidAtlantic Ridge at Kane (MARK) area, during the Hydrosnake (1988) and Gravinaute (1993) cruises. The primary goal of the seafloor surveys was to test for the presence of a magma reservoir beneath the axial neovolcanic ridge. First, a forward two-dimensional (2-D) model of the crustal structure across the axis is fit to observed gravity anomalies, using constraints from geological and structural observations. Bouguer anomalies computed from sea bottom measurements and downward continuation of sea surface measurements both constrain the forward modeling. This forward model is the starting point of a 2-D Monte Carlo inversion of seafloor and sea surface data. In addition to the crustal thickness variations along-axis, our data document the amplitude variations of the crustal thickness and/or its density in the across-axis direction. The model resulting from our inversion exhibits several features of the crustal structure in the MARK area: (1) The presence of a low-density $\left(\Delta \rho=-300 \pm 50 \mathrm{~kg} / \mathrm{m}^{3}\right)$ body beneath the neovolcanic ridge is suggested and could correspond to a magma chamber, or more probably to a highly hydrothermally fissured zone. (2) Both long- and short-wavelength gravity signals exhibit a difference between the western and eastern sides of the axial domain: the mean value and the amplitude of Bouguer anomalies are higher on the western part. This difference suggests that axial processes, in this area, are very asymmetric. (3) Abyssal hills are not associated with a single gravity signature: for instance, on the west side of the axis, one of the explored hills has no Bouguer anomaly and is interpreted as a neovolcanic ridge, whereas the others are associated with a shifted Bouguer anomaly high and are interpreted as having thinner magmatic crust. (4) The last feature of the crustal fabric we document here is the asymmetric emplacement of some deep rocks outcrops. In the MARK area, we find that "Pink Hill," a topographic high where serpentinized peridotites are outcropping, is much more serpentinized on its east flank, toward the axial valley, than on its west flank. Alteration occurring mainly by fluid circulation through faulted zones, the asymmetric serpentinization suggests that deep-origin rocks have outcropped by means of a main fault zone and are not emplaced by diapirism.
\end{abstract}

\section{Introduction}

Years of sampling and dredging of the oceanic seafloor have revealed that the upper part of the oceanic crust is mainly formed by basalts, but also that ultramafic rocks and deep-origin magmatic rocks are commonly observed.

\footnotetext{
'Now at Marine Physical Laboratory, Scripps Institution of Oceanography, La Jolla, California.

${ }^{2}$ Also at Centre National de la Recherche Scientifique, IPG Paris, France.

${ }^{2}$ Also at Institut Francais de Recherche Scientifique pour le Development en Coopération, Laboratoire de Géophysique, Bondy, France.
}

Copyright 1998 by the American Geophysical Union.

Paper number 97JB02542.

0148-0227/98/97JB-02542\$09.00
Knowledge of the oceanic crustal structure at depth would help in understanding its formation. In this paper, the crustal structure is investigated using both seafloor and sea surface gravity data. We document an asymmetry of the ultramafic rocks outcropping mechanism, as well as a difference in the crustal structure between the two flanks of the ridge axis.

Numerous surveys have documented gravity field variations along the mid-ocean ridges. The Mid-Atlantic Ridge (MAR) large-scale topography creates large amplitude free-air gravity anomalies. Correcting for this topography using assumed constant crustal density and thickness produces mantle Bouguer anomalies (MBA) which show quasi-circular lows correlated with the bathymetric segmentation of the ridge axis [Kuo and Forsyth, 1988; Lin et al., 1990; Blackman and Forsyth, 1991; Morris and Detrick, 1991; Deplus et al., 1992; Rommevaux et al., 1994; Detrick et al., 1995; Maia and Gente, 1997]. When 
the estimated gravity effect of the cooling of the lithosphere away from the axis is subtracted from the MBA, a negative residual mantle Bouguer anomalies (RMBA) is commonly observed at the segment centers. This could be due both to the temperature pattern in the upper mantle and to variations of the thickness and/or density of the crust [Lin et al., 1990]. However, quantification of the possible thermal effect on the gravity field [Phipps Morgan and Forsyth, 1988; Lin and Phipps Morgan, 1992; Sparks et al., 1993] , comparisons with off-axis MBA amplitudes along an isochron [Deplus et al., 1992; Rommevaux et al., 1994], and observations of variations in crustal thickness by seismic refraction studies show that crustal thickness variations account for almost all the RMBA variations along axis [Tolstoy et al., 1993].

Some studies, based on the analysis of seismic and structural data, propose that the crustal thickness variations, and thus the segmentation, have tectonic origins [Mutter and Karson, 1992]. However, most studies interpret the segmentation as the by product of mantle diapirism [Schouten and Klitgord, 1982; Francheteau and Ballard, 1983; Whitehead et al., 1984; Crane, 1985; Schouten et al., 1985b; Lin et al., 1990]. By showing the deviations from a constant thickness and density crustal model (usually $6 \mathrm{~km}$ thick and $2700 \mathrm{~kg} / \mathrm{m}^{3}$ dense), the RMBA provides constraints on the accretion processes.

Geological observations clearly show the nonuniformity of the crust: deep origin rocks with a variety of densities have been frequently observed along the MAR [e.g., Nicholls et al., 1964; Christensen and Salisbury, 1975; Shipboard Scientific Party, 1979; Karson and Dick, 1983; Shipboard Scientific Party, 1988; Mével et al., 1991; Cannat, 1993]. Cannat et al. [1995] point out that, along the MAR, south of the Kane fracture zone, deep rock exposures (gabbros and serpentinized peridotites) are located in an area where the MBA is high. This observation reinforces the idea that high MBA zones correspond to thin magmatic crust areas.

To investigate the crustal density pattern requires shortwavelength gravity signals, corresponding to shallow and small bodies. For short-wavelength signals, the amplitude of the anomaly decreases rapidly with increasing observation distance. By getting closer to the gravity sources, seafloor measurements can recover the short-wavelength signal created by crustal bodies. Several previous seafloor gravity studies have demonstrated the ability of these methods to provide reliable estimates of the mean density of the oceanic crust and its fine-scale variations [Luyendyk, 1984; Hildebrand et al., 1990; Dubois et al., 1992; Holmes and Johnson, 1993; Stevenson et al., 1994; Stevenson and Hildebrand, 1996]. In addition, gravity data collection at different altitude levels gives some additional constraints on the depth of sources [Bowin et al., 1986; Dubois and Deplus, 1989].

We acquired 121 seafloor gravity data during two submersible cruises, Hydrosnake (1988) and Gravinaute (1993), with a Worden Geodetic and a Scintrex CG3-M gravity meter respectively. We used on-land type meters that we manipulated within a submersible stabilized on the seafloor. A similar data acquisition procedure has been described in previous surveys [Luyendyk, 1984; Dubois and Deplus, 1989; Holmes and Johnson, 1993]. We also have a set of sea surface data from other surveys [Morris and Detrick, 1991; Needham et al., 1992; Gente et al., 1991a].

The Mid-Atlantic Ridge at Kane fracture zone (MARK area) is an intensively surveyed portion of the Mid-Atlantic Ridge; nevertheless, the accretion mechanisms are not fully understood. The available geological and geophysical data, in addition to our gravity data, are combined to construct a model of the MARK area crustal structure. This model is then used as a starting model for the gravity anomaly inversion.

\section{Geological and Geophysical Settings and Main Questions Raised}

Our study (Figures 1 and 2) is focused on a 40-km segment of the MAR, limited to the north by the Kane Fracture Zone and to the south by a nontransform offset at $23^{\circ} 15^{\prime} \mathrm{N}$. According to seismic refraction [Purdy and Detrick, 1986] and gravity interpretation [Morris and Detrick, 1991; Deplus et al., 1992; Maia and Gente, 1997], this nontransform offset is the location of a step in the mean value of the crustal thickness: the crust is 6-7 km thick south of the offset and only 4-5 km thick north of it [Purdy and Detrick, 1986]. Morris and Detrick [1991] pointed out that the gravity anomaly pattern just south of the Kane fracture zone is more complex than the simple bull's eyes pattern described for some other parts of the MAR, whereas south of the $23^{\circ} 15^{\prime} \mathrm{N}$ offset, a distinct circular low of 20 mGal in the residual MBA occurs [Deplus et al., 1992; $M a^{\prime} a$ and Gente, 1997].

The axial domain of our study area is characterized by a 13-km-wide rift valley. The presence of a $600-\mathrm{m}$-high neovolcanic ridge within the rift valley, the Snake Pit Ridge, exhibiting fresh lava flows, reveals present-day magmatic activity [e.g., Karson et al., 1987; Gente et al., 1991b]. Faults are numerous, with throws of several tens or hundreds of meters, and some of them are active outside of the axial domain [Durand et al., 1996]. The tectonic activity in the axial domain is thought to accommodate an important part of the total seafloor spreading in this area [Karson et al., 1987; Mével et al., 1991; Mutter and Karson, 1992].

The axial valley, as well as the off-axis domain, are clearly asymmetric. The average depth of the western flank is about $500 \mathrm{~m}$ shallower than the eastern flank, and the west valley wall culminates at $2600 \mathrm{~m}$, whereas the eastern wall is slightly deeper than $3000 \mathrm{~m}$. Variations in relief are also larger on the west flank than on the east flank. In addition, differences in the petrology (deep origin rocks on the west side of the valley) have been documented [Karson and Dick, 1983; Dick, 1989; Mével et al., 1991]. Magnetic anomalies show a spreading rate of $1.4 \mathrm{~cm} / \mathrm{yr}$ to the west and $1.1 \mathrm{~cm} / \mathrm{yr}$ to the east over the past $36 \mathrm{My}$ [Schouten et al., 1985a; Schulz et al., 1988]. This asymmetry may be partly due to axis jumps; such events have been documented by the duplication of the Jaramillo event $(0.8 \mathrm{Ma})$ and/or anomaly $2 \mathrm{a}(1.9 \mathrm{Ma})$ on the west flank [Schulz et $a l ., 1988]$. The proximity of the Kane Fracture Zone, which offsets the ridge axis over $150 \mathrm{~km}$ in a left-lateral sense, may have a key influence on the above described asymmetry. It has been commonly observed that a ridge/transform intersection axis is associated with an asymmetric inside/outside corner geometry, the inside corner being higher and steeper [Searle and Laughton, 


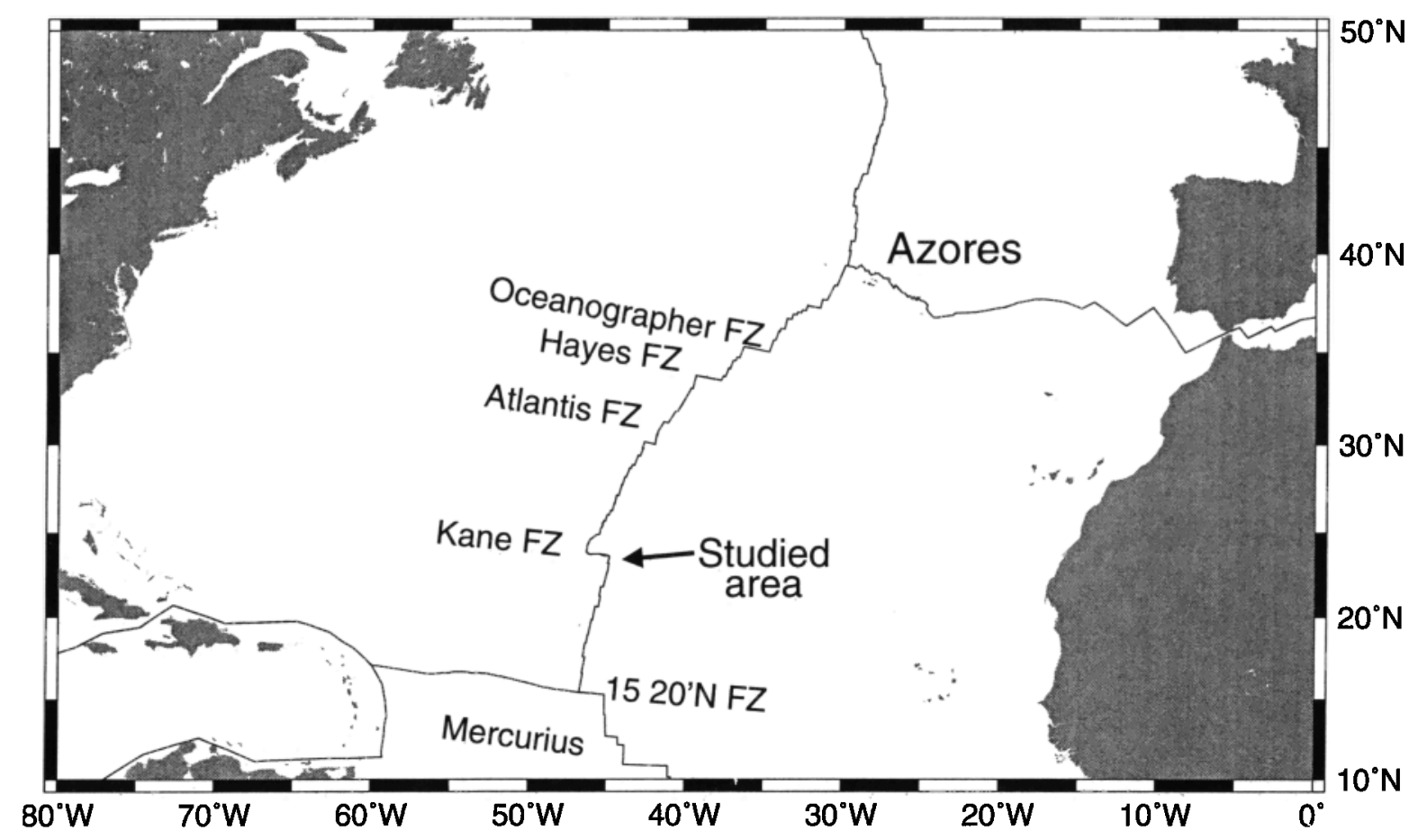

Figure 1. Location map of the studied area. Plates limits and main fracture zones are shown on the map.

1977; Severinghaus and Macdonald, 1988; Tucholke and Lin, 1994; Escartin and Lin, 1995]. One of the question we address in the present paper is whether the morphological and geological asymmetry is related to a difference in the crustal structure between the axial flanks.

Abyssal hills, of the order of a thousand of meters high, are spaced $\sim 10 \mathrm{~km}$ apart in the across-axis direction on both flanks of the ridge. Several tectonic models have been proposed for the origin of these hills, such as back-tilting [Macdonald and Luyendyk, 1977; Tapponnier and Francheteau, 1978], off-axis dismembering by outward facing faults [Van Andel and Bowin, 1968; Macdonald and Atwater, 1978] or reverse faulting [Harrison, 1974] of the valley walls. Some models favor the influence of an alternation between magmatic and amagmatic stages in the spreading [Vogt et al., 1969; Kappel and Ryan, 1986; Gente, 1987; Malinverno and Pockalny, 1990; Macdonald et al., 1996].

Deep origin rock exposures, such as gabbros or serpentinized peridotites, are common in the area and have been documented by studies based on drill cores, dredges, and submersible observations [Leg 109 Scientific Party, 1986; Leg 109 Shipboard Scientific Party, 1988; Dick, 1989; Gente et al., 1989; Juteau et al., 1990; Mével et al., 1991; Auzende et al., 1993; Durand et al., 1996]. The location and the occurrence of these rocks outcrops have been discussed in several papers [Mével et al., 1991; Cannat, 1993; Durand et al., 1996]. Our main concern here is to better understand the emplacement process by studying the geometry of these massifs. Several emplacement models have been proposed; they can be roughly divided into three classes. In the first class, the mantle rises up by diapirism subsequent to the decrease in density due to the serpentinization [Aumento and Loubat, 1971; Bonatti and Honnorez, 1976; Francis, 1981; Zonenshain et al., 1989]. Serpentini- zation results from the hydration of olivines in the peridotites; it is induced by the water circulation within the crust, which is mainly driven by the porosity and fissure distribution. Therefore the serpentinization pattern gives evidence of tectonic events and can help provide insight on the mechanism that makes outcrops of mantle rocks. Petrostructural analysis has shown, at least in some places (for instance, at Ocean Drilling Program ODP Site 670, located on the western wall of the MAR at $23^{\circ} 10^{\prime} \mathrm{N}$ ) that serpentinization occurs after the outcrop was emplaced and therefore cannot be responsible for the uplift [Cannat et al., 1990; Cannat, 1993]. In the second class of models, deep rock outcropping is related to axial valley wall formation by either symmetric processes [Sleep, 1969; Osmaston, 1971; Tapponnier and Francheteau, 1978] or asymmetric ones [Karson and Dick, 1983; Karson et al., 1987; Karson, 1990; Karson and Rona, 1990; Mutter and Karson, 1992; Tucholke and Lin, 1992; Tucholke and Lin, 1994]. In the third class of models, episodes of very low magma production allow tectonic spreading to dismember the existing lithosphere and thus deep rocks such as gabbros or peridotites may outcrop [Dick et al., 1981; Mével et al., 1991; Cannat, 1993].

Finally, we will investigate the possible existence of a magma chamber beneath the Snake Pit. With the possible exception of the Reykjanes Ridge [Sinha et al., 1997], so far, magma chambers have been evidenced only in fast or intermediate spreading contexts [Herron et al., 1978; 1980; Hale et al., 1982; Mutter et al., 1984; Morton and Sleep, 1985; Detrick et al., 1986; 1987; Kent et al., 1990; Vera et al., 1990; Caress et al., 1992]. If some stable magma chambers could exist in slow spreading ridge contexts, the MARK area, beneath the Snake Pit ridge, would be a good candidate for the location of such a body. Here, there is evidence for present-day volcanic activity and the 


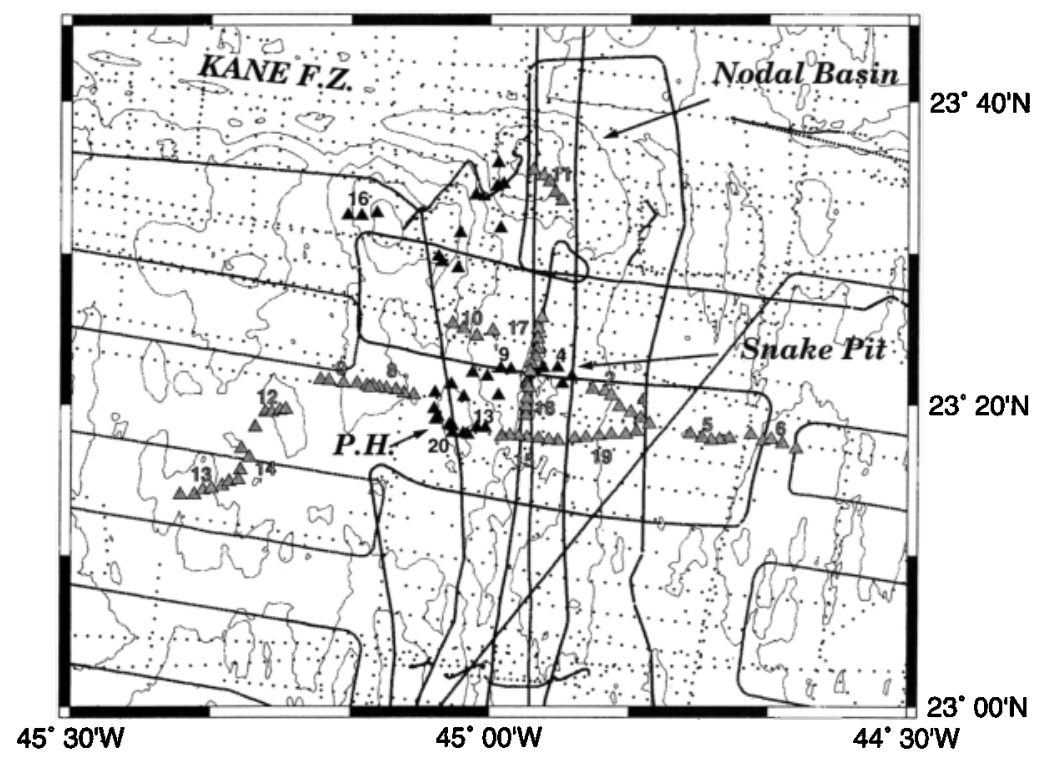

Figure 2. Surface (dots) and seafloor (triangles) gravity measurement points. Gray triangles are for Hydrosnake points and the black ones are for Gravinaute points. The gray and black numbers correspond to the dive index. The data sampling being shorter on the two R/V L'Atalante cruises, those cruises can be recognized on the map by continuous tracks. Note that most of the east-west seafloor profile is coincident with a single surface profile (from $R / V$ Conrad). These profile data are shown in Figures 3, 5, 6 and Plate 2.

thermal flux induced by a magma body could be the driving mechanism for the intense hydrothermal activity at the summit of the ridge. However, Detrick et al. [1990] reported no evidence from seismic refraction data for the presence of a magma chamber; their experiment was conducted from the sea surface and thus is subject to diffraction and scattering due to the topography. New insights on these seismic data, associated with geochemical evidence, suggests that a magma reservoir is likely to be located beneath the Snake Pit neovolcanic ridge [Calvert, 1995]. Sea bottom gravity measurements may provide supporting evidence for magma bodies, as shown by previous studies [Hildebrand et al., 1990]. Our seafloor gravity survey was conducted to test for the presence of a possible magma chamber beneath the Snake Pit.

In summary, the main questions we address in the present paper are (1) Is the morphological asymmetry observed between the western and the eastern part of the axial domain related to an asymmetry in the crustal structure? (2) What crustal thickness variations are associated with small off-axis hills and how are these hills constructed? (3) What is the structural geometry of hills where peridotites are exposed and how were these rocks emplaced? (4) Is there a magma chamber beneath the Snake Pit neovolcanic ridge as suggested by the recent magmatic activity and hot hydrothermal fluids?

\section{Data Acquisition and Reduction}

\subsection{Multibeam Bathymetry and Sea Surface Gravity Data}

The MARK area has been extensively surveyed for geological and geophysical studies. Multibeam bathymetry and sea surface gravity data were collected with the R/V Conrad in 1984 as part of the ODP predrilling site survey of the axial area [Detrick et al., 1984; Morris et al., 1989; Morris and Detrick, 1991]. We complemented these data by those collected in 1991 during the SIGMA [Needham et al., 1992] and SEADMA [Gente et al., 1991a] cruises of the R/V L'Atalante. On both cruises, navigation was constrained by nearly continuous Global Positioning System (GPS) data recording and gravity measurements were performed with a KSS30 Bodenseewerk gravimeter. We also add some older gravity data available in the National Geophysical Data Center (NGDC) data bank. The shipboard gravity data tracks are shown on Figure 2. All the cruises are tied to the International Gravity Standardization Net 71 (IGSN 71) network, and free-air anomalies were calculated using a theoretical field estimated with International Association of Geodesy (IAG) 67 formula, compatible with the IGSN 71 gravity network [Milson, 1989]; the final crossover standard deviation is estimated to be $2 \mathrm{mGal}$ [Maia and Gente, 1997].

\subsection{Seafloor Gravity Data}

Seafloor gravity data were collected during two cruises with the French R/V Nadir and the submersible Nautile: the Hydrosnake cruise in 1988 [Mével et al., 1989] and the Gravinaute cruise in 1993 [Dubois et al., 1994]. Thirtynine gravity measurements were performed during 12 dives on the Hydrosnake cruise, which had mostly geological objectives. The Gravinaute cruise was devoted to a seafloor geophysical survey of this area: 16 dives were devoted to seafloor gravity measurements and 3 dives were devoted to both magnetotelluric and gravity measurements, resulting in $\mathbf{8 2}$ gravity stations. The total number of measurements in the area is 121 conducted at 115 different sites (Figure 2). The stations are mainly located along two profiles: a 15$\mathrm{km}$-long profile along the summit of the Snake Pit neovolcanic ridge and a $75-\mathrm{km}$ long profile across the axis.

3.2.1. Gravity measurement. Each gravity measurement required the submersible to be stabilized on the seafloor (weighting it by rock samples when necessary). The 
Hydrosnake cruise measurements were made with a Geodetic Worden meter, whereas a Scintrex CG3-M gravity meter was used during the Gravinaute cruise. Each measurement made with the Scintrex CG3-M meter resulted in the average of 120 measurements made over 2 minutes. Continuous automatic tilt corrections, useful in unstable areas, were performed [Hugill, 1984]. In addition, a LaCoste and Romberg ( $\mathrm{G}$ type) gravity meter was on board during each dive of the Gravinaute cruise and some measurements were duplicated using both meters to better control the instrumental drift and the measurement repeatability. Finally, the measurement uncertainty is estimated to be lower than $0.5 \mathrm{mGal}$ and $0.1 \mathrm{mGal}$ when measurements are performed with a Worden or a Scintrex type gravimeter, respectively. These values are large compared with onland values (less than $0.05 \mathrm{mGal}$ ) but are low with respect to the crossover errors in multitrack sea surface free-air anomaly maps.

3.2.2. Positioning. The Nautile was navigated on the seafloor by long baseline acoustic signals from an array of beacons. Two or three beacons were emplaced every day; the positioning of each beacon was first taken at the landing point and then adjusted by triangulation from the shipboard Global Positioning System (GPS) navigation. The absolute positioning accuracy is limited by the GPS to be of the order of $50 \mathrm{~m}$. Three relative positions are acquired simultaneously: two long base acoustic navigation systems (one received on the mother ship and the other on the submersible) and an integrated navigation using the measured speed and heading of the submersible. For the more recent Gravinaute cruise, we reprocessed the navigation after the cruise, taking into account information extracted from the three navigation sources. A navigation check was given by the comparison between seafloor summits observed from the submersible and those derived from a bathymetric map. The comparison exhibits a difference smaller than $50 \mathrm{~m}$ in position.

3.2.3. Depth estimation. The depth estimates are derived from the submersible pressure gauge. The pressure gauge has a resolution of $0.1 \mathrm{~m}$, but the precision of the absolute depth is not so accurate due to uncertainties in the gauge calibration and in the pressure-to-depth conversion. An error in the depth, which is proportional to the depth itself, is possible and should be taken into account during the data reduction.

3.2.4. Instrumental drifts. The instrumental drift effect has been removed for the two sets of data, using both the drift estimation from IGSN 71 reference stations at the beginning and at the end of each cruise and the drift estimation from seafloor measurements at a base-station called "La roue." La roue is a train wheel mark, left at an ODP hole on the summit of the Snake Pit ridge, which has been used as a reference station during Hydrosnake cruise (three measurements) and reoccupied during the Gravinaute cruise (four measurements). For the Gravinaute cruise, we obtained nearly exactly the same value for both drift estimates $(0.0003 \mathrm{mGal} / \mathrm{d}$ difference between the estimates made from IGSN 71 reference stations and from La roue station measurements). For the Hydrosnake cruise, the sea bottom reference station La roue has been occupied only in the first half of the cruise (dive HSN 4 and dive HSN 9), thus we used the drift from IGSN 71 stations. A difference of only $1.3 \mathrm{mGal}$ was observed between the mean value at La roue for Gravinaute and Hydrosnake cruises; Hydrosnake data were adjusted to be in agreement with Gravinaute ones.

3.2.5. Tidal effects. Tidal effects can be divided into an ocean tide and an Earth tide components. In the studied area, the water column thickness variations are less than 30 cm [Schwiderski, 1980], and thus the ocean tide has a negligible gravity effect (less than $0.06 \mathrm{mGal}$ ) compared to our data accuracy. The Earth tide effects are larger, but we choose not to apply any tide corrections, since they are within the gravity measurement errors bars for sea surface data [Stevenson et al., 1994] and within the terrain effect estimation errors bars for sea-floor data [Luyendyk, 1984]. For drift estimation at the reference station La roue, a higher accuracy is required and we took into account a solid Earth tide correction [Longman, 1959].

3.2.6. Free-water anomalies. The free-water reduction is applied to estimate the theoretical gravity field on the seafloor. It can be written as a free-air correction plus twice the effect of a slab of water [Luyendyk, 1984; Dubois and Deplus, 1989; Hildebrand et al., 1990]. As for on-land surveys, we used the free-air vertical gradient of 0.3086 $\mathrm{mGal} / \mathrm{m}$ [Heiskanen and Vening Meinesz, 1958]. The mean density of the water slab increases with the slab thickness; it varies from $1032 \mathrm{~kg} / \mathrm{m}^{3}$ for a depth of $2000 \mathrm{~m}$ to 1041 $\mathrm{kg} / \mathrm{m}^{3}$ for a depth of $6000 \mathrm{~m}$. Considering the mean depth of the seafloor measurements, we used a seawater density of $1035 \mathrm{~kg} / \mathrm{m}^{3}$ and thus a free-water gradient of 0.2218 $\mathrm{mGal} / \mathrm{m}$.

\section{Bouguer Anomalies}

Seafloor free-water anomalies, as well as sea surface free-air anomalies, are dominated by the gravity signal due to the bathymetry. The Bouguer correction consists of removing the gravity effect of the seafloor topography from the free-water anomalies and requires a precise 3-D knowledge of the surrounding bathymetry and the associated density contrast.

\subsection{Computation of a Digital Terrain Model}

We use two different digital terrain models (DTM). The first is a 500-m grid spacing DTM computed from surface multibeam bathymetric data, complemented on the edge with data from the worldwide file ETOPO-5. We use a least squares smooth fitting method [Inoue, 1986] to smooth the junction between the two sets of data. The grid extends in longitude from $47^{\circ} \mathrm{W}$ to $43^{\circ} 30^{\prime} \mathrm{W}$ and in latitude from $22^{\circ} \mathrm{N}$ to $25^{\circ} \mathrm{N}$ and was used to estimate the contribution of the terrain gravity effect on the surface measurements and of the far terrain on the sea-floor measurements. A second DTM, with a smaller $150-\mathrm{m}$ grid spacing, was used to estimate the fine scale terrain contribution on the seafloor measurements. This DTM was computed from a combination of lower-resolution but higher coverage data from surface multibeam bathymetric surveys (tens of meters precision) and of seafloor higher-resolution bathymetry data along the dive profiles (meter precision). It extends in longitude from $45^{\circ} 30^{\prime} \mathrm{W}$ to $44^{\circ} 30^{\prime} \mathrm{W}$ and in latitude from $23^{\circ} \mathrm{N}$ to $23^{\circ} 45^{\prime} \mathrm{N}$. After reprocessing the submer- 
sible navigation and analyzing the video recordings, we obtained accurate bathymetry and navigation data along the dive tracks with an elevation precision better than $10 \mathrm{~m}$. Most of the dive tracks were perpendicular to the structural direction; thus, for 13 of 16 across axis dives, we assumed that the bathymetry was locally two-dimensional and generated $300 \mathrm{~m}$-wide bands of high-resolution bathymetry centered on the dive tracks. We then computed a DTM using a weighted least squares smooth fitting interpolation [Inoue, 1986] of the sea surface and seafloor bathymetric data. The precision ratio between seafloor and sea surface bathymetric data used in the weighted interpolation is 1 to 5. The improvement in the estimation of the nonslab gravity contribution to the seafloor gravity field may be of the order of $2 \mathrm{mGal}$ in steep bathymetry areas.

\subsection{Density Contrast at the Water/Crust Interface}

Seaffoor densities depend on the igneous structure but may be more closely related to changes in porosity and alteration [e.g., Carlson and Herrick, 1990]. One way of estimating a mean density is to derive it from the gravity and bathymetry data [Parasnis, 1962; Nettleton, 1976]. These methods require the Bouguer anomaly to be quite constant and statistically independent of the seafloor topography. Using the Nettleton [1976] visual method on the seafloor across-axis profile, we have found a high variability of the density contrast between the crust and the water, ranging from about 1300 to $1900 \mathrm{~kg} / \mathrm{m}^{3}$, with $1600 \mathrm{~kg} / \mathrm{m}^{3}$ being a representative mean value (Figure 3 ). The Parasnis [1962] method (including a terrain correction term and applied where the Bouguer anomaly gradient is low) yields a mean density contrast of $1630 \mathrm{~kg} / \mathrm{m}^{3}$ for the water/crust interface; we used this value in subsequent analyses. It is lower than the density measured from samples, which is expected due to megascopic voids and is consistent with gravity derived densities for other ridge crest sites [Luyendyk, 1984; Hildebrand et al., 1990; Holmes and Johnson, 1993; Stevenson and Hildebrand, 1996]. Deviations from this uniform density are analyzed further in sections 6.3 and 6.4 .

\subsection{Computation Method}

Bouguer corrections include both slab and nonslab contributions of the topography to the gravity signal. Separating these two terms allows us, when required, to use a different origin depth to calculate slab and nonslab corrections. For seafloor measurements, the slab term has been computed using the submersible measured depth at the station, whereas the nonslab term is estimated from the DTM described in section 4.1, interpolating from a rectangular grid.

We estimated the water/crust interface contribution to the gravity signal by a numerical integration using GaussLegendre quadratures [Parker, 1996]. Terrain corrections for sea bottom measurements have been separated into nearby and remote effects. For the nearby corrections, we used the 150-m step computed DTM, described above. The remote terrain contribution on seafloor and surface measurements has been estimated from the 500-m grid step DTM by a simple Gauss quadrature integration.

The sea surface Bouguer anomalies were then interpolated onto a 500-m rectangular grid, with the smooth surface fitting method of Inoue [1986]. Performing a unique inversion with Bouguer anomalies computed both on the sea bottom and on the sea surface requires a single reference level, chosen at the deepest gravity station.

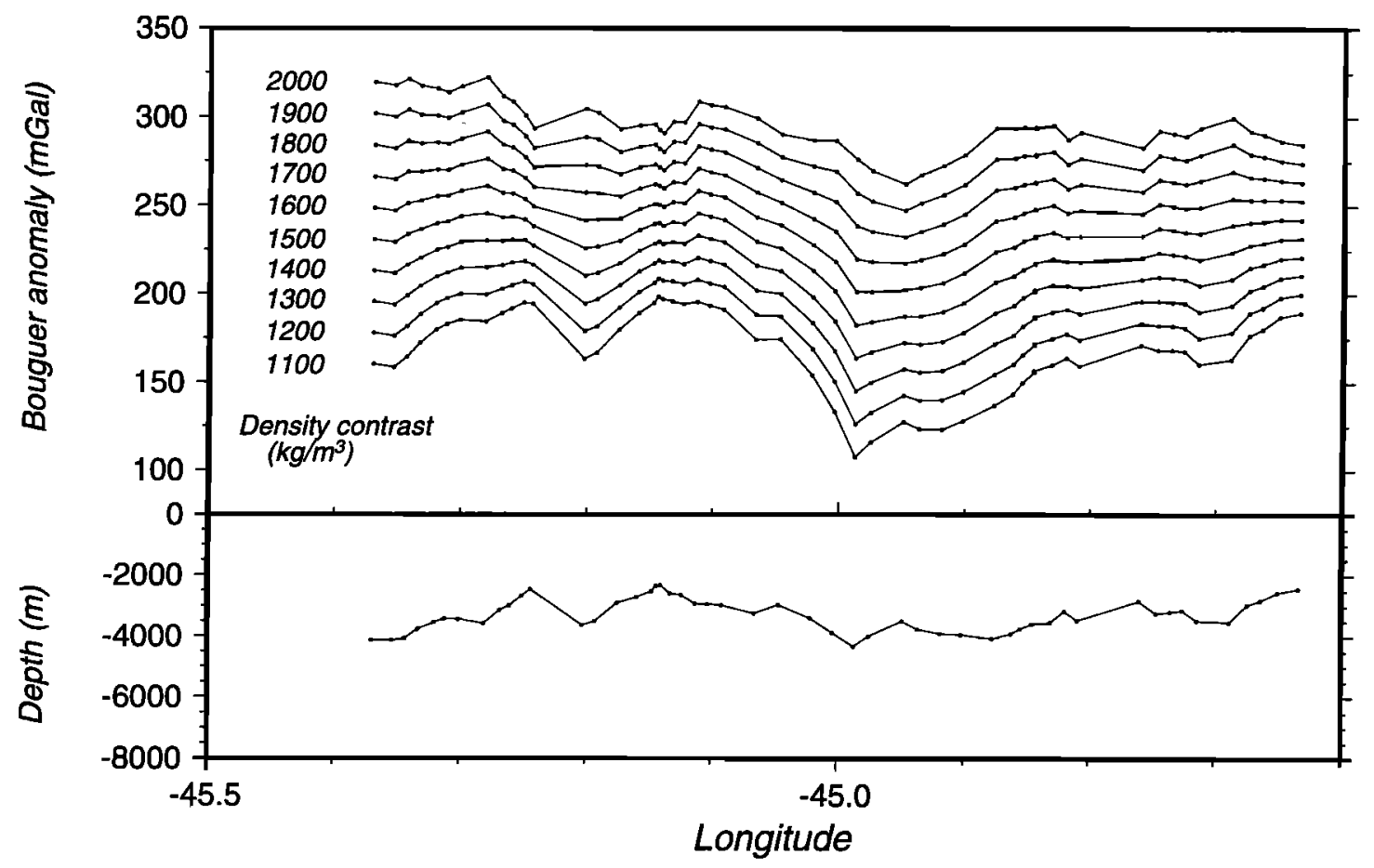

Figure 3. Density estimation from Nettleton [1976] method on an east-west sea bottom profile (located in Figure 2). The bathymetric profile from submersible observations. (top) The Bouguer anomaly calculated with different crust/water density contrasts (ranging from 1000 to $2000 \mathrm{~kg} / \mathrm{m}^{3}$ ); $1600 \mathrm{~kg} / \mathrm{m}^{3}$ has been chosen as the mean density contrast which best decorrelates gravimetric and bathymetric signals at short wavelengths. 


\subsection{Error Estimation in the Resulting Bouguer Anomalies}

The Bouguer anomaly uncertainty depends on the initial uncertainty of the measurements and on the various corrections. The uncertainty is about $2-3 \mathrm{mGal}$ for the sea surface free-air anomalies [Maia and Gente, 1997] and less than $0.5 \mathrm{mGal}$ and $0.1 \mathrm{mGal}$ for Hydrosnake cruise and Gravinaute cruise seafloor measurements, respectively.

Neglecting the Earth sphericity, as well as taking an approximate value for the free-water gradient leads to an error proportional to the water depth. On the other hand, the density used for the Bouguer reduction is derived from the relation between gravity and depth. Therefore all the discrepancies related to depth-type correction are balanced by the use of a "pseudo-density" contrast in the slab correction. Thus depth-related errors should not be reflected in the Bouguer anomalies. Finally, the relative error due to the above sources is estimated to be of the order of $1.0 \mathrm{mGal}$ for both Gravinaute and Hydrosnake data.

Another source of uncertainty is introduced by the nonslab part of terrain corrections and is not directly related to depth uncertainty. The contribution of the topography to the gravity field increases when the distance between the relief and the measurement location decreases; as often as it was possible, we did not locate the gravity stations close to fault scarps. Errors in the nonslab terrain contribution are estimated to be up $1 \mathrm{mGal}$ for the seafloor gravity stations. Overall, the relative quadratic root mean square error for seafloor Bouguer anomalies calculated from Hydrosnake and Gravinaute cruise is better than 1.5 mGal.

\subsection{Resulting Seafloor and Sea surface Bouguer Anomalies}

The main features of Bouguer anomalies computed from the seafloor and sea surface measurements are similar, with higher amplitudes for those computed at the seafloor (Plate 1). The principal characteristics of Bouguer anomalies are as follows:

1. The axial valley is associated with a negative Bouguer anomaly. In the southern half of the studied area, the minimum is located in the active part of the axis. It is shifted toward the east in the northern part, where the minimum is located almost $15 \mathrm{~km}$ southeast of the nodal basin. At $23^{\circ} 35^{\prime} \mathrm{N}$, the neovolcanic activity located from morphological data is at an equal distance from the nodal basin and the minimum in Bouguer anomaly.

2 . From the surface anomalies, the ridge transform intersection massif is clearly associated with a positive Bouguer anomaly of $20 \mathrm{mGal}$.

3. The surface Bouguer anomalies reveal a pronounced asymmetry between the flanks of the ridge. On average, the anomalies are more negative on the east flank and do not present high-amplitude variations. On the west side the anomalies are about $20 \mathrm{mGal}$ higher and have greater variations.

The asymmetry in the Bouguer anomaly between the two sides of the axis can be partly explained at a regional scale. In section 5.1 , we analyze the regional gravity field by performing a spectral analysis to examine if there are differences in the mean depth of gravity sources between the two axis flanks.

\section{Computation of Residual Sea Surface and Seafloor Bouguer Anomalies}

\subsection{Spectral Analysis of Sea Surface Data}

The depth of crustal density contrasts can be derived from the study of the gravity energy spectrum. When $E(k)$ is the gravity signal energy as a function of the wavenumber $k$, if the source distribution is statistically homogeneous (an assumption that may have merit but is not strictly proven), then the depth $d$ from the top of the sources to the measurement can be expressed as [Spector and Grant, 1970; Poudjom Djomani et al., 1995]

$$
d=\frac{\Delta \log \mathrm{E}(\mathrm{k})}{2 \Delta \mathrm{k}}
$$

We performed a spectral analysis of the sea surface Bouguer anomalies from two regions in the study area. The first one, on the west flank, is $50 \mathrm{~km}$ in longitude by $75 \mathrm{~km}$ in latitude; it is limited on the north by the south wall of the Kane fracture zone and on the east by the summit of the west valley wall. The second one, on the east flank, is 35 $\mathrm{km}$ in longitude by $75 \mathrm{~km}$ in latitude; it is limited on the north by the south wall of the Kane fracture zone and on the west by the summit of the east valley wall. We calculated the spectra with the ring method [Hahn et al., 1976], on $500 \mathrm{~m}$ step grids. We are aware that the grid sizes are small for spectral analysis, but due to the high stability of the values when tuning the radius of the ring and slightly changing the size of the grid, we are confident in the result [Poudjom Djomani, 1993]. The comparison between the east and the west axial valley flanks shows that the interface which creates the main gravity anomalies is $6-7 \mathrm{~km}$ below sea surface on the west and 11-12 km below sea surface on the east, respectively (Figure 4). Other studies have also documented a crustal thickening of about $2 \mathrm{~km}$ on the east flank of the ridge axis [Morris and Detrick, 1991; Maia and Gente, 1997] ; the values derived from the spectral analysis are larger but in the same sense as previous studies.

Our result supports a difference in the mean crustal thickness between the two sides of the axis; a thermal effect alone could probably not create this asymmetry. In addition, here we do not observe a correlation between negative Bouguer areas (hotter areas) with shallower bathymetric zones, as is usually seen.

\subsection{The Regional Contribution to the Surface and the Seafloor Gravity Signal}

The gravity effect of the lithospheric cooling away from the axis and the presence of the Kane fracture zone are thought to be the main contributions to the regional trend. The gravity effect of the lithospheric cooling away from the axis can be modeled directly, using the seafloor age based method of Parsons and Sclater [1977] [Rommevaux et al., 1994] or a 3-D passive mantle flow modeling [Phipps Morgan and Forsyth, 1988], or it can be approximated by low-pass filtering the data [Deplus et al., 1992; Maia and Gente, 1997]. Each method presents some disadvantages: the first one allows asymmetric spreading but neglects ridge-axis offsets, whereas the second one takes into account axis discontinuities but requires a simple and symmetric pattern of the spreading. The studied area is 
mGal

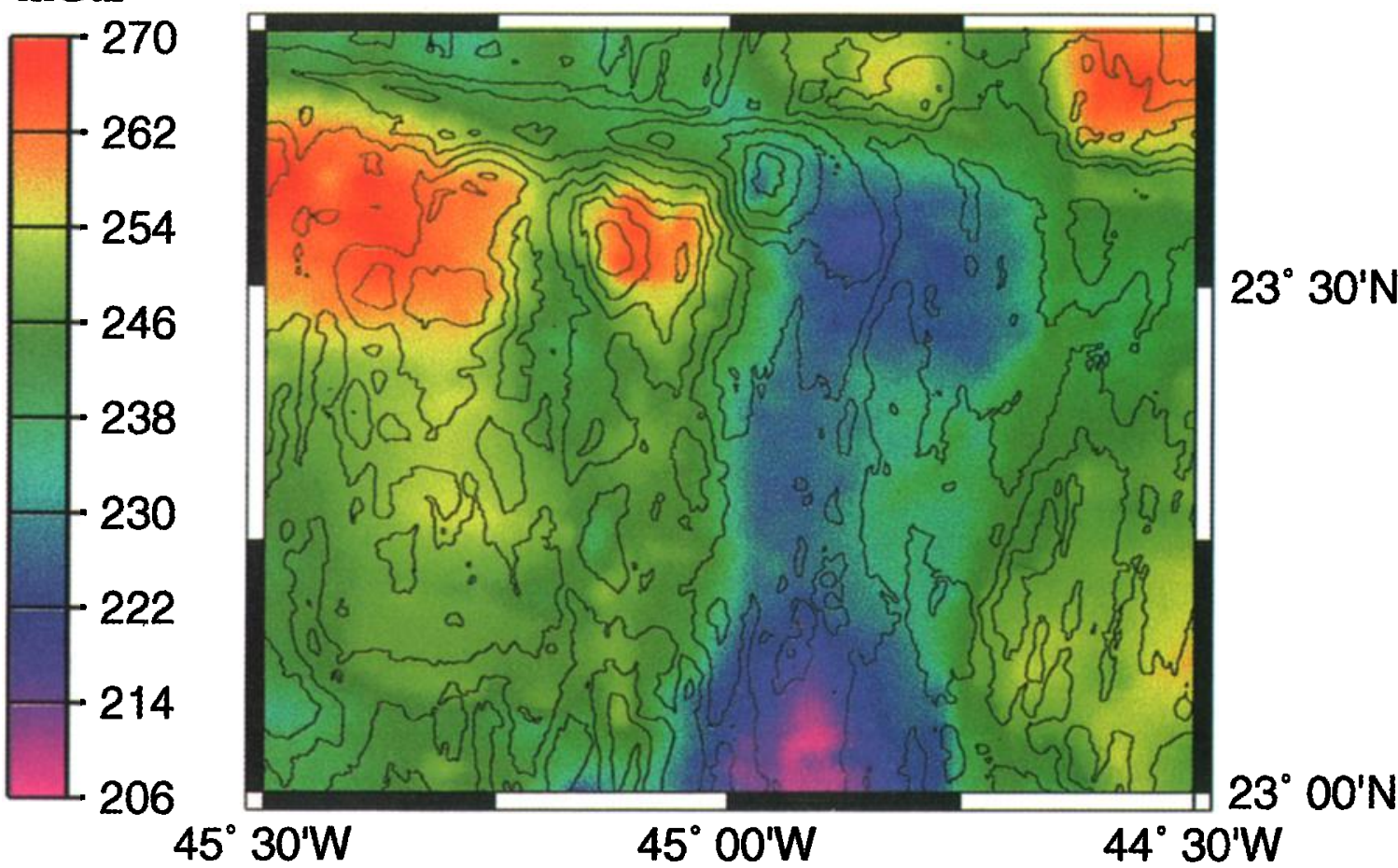

$\mathrm{mGal}$

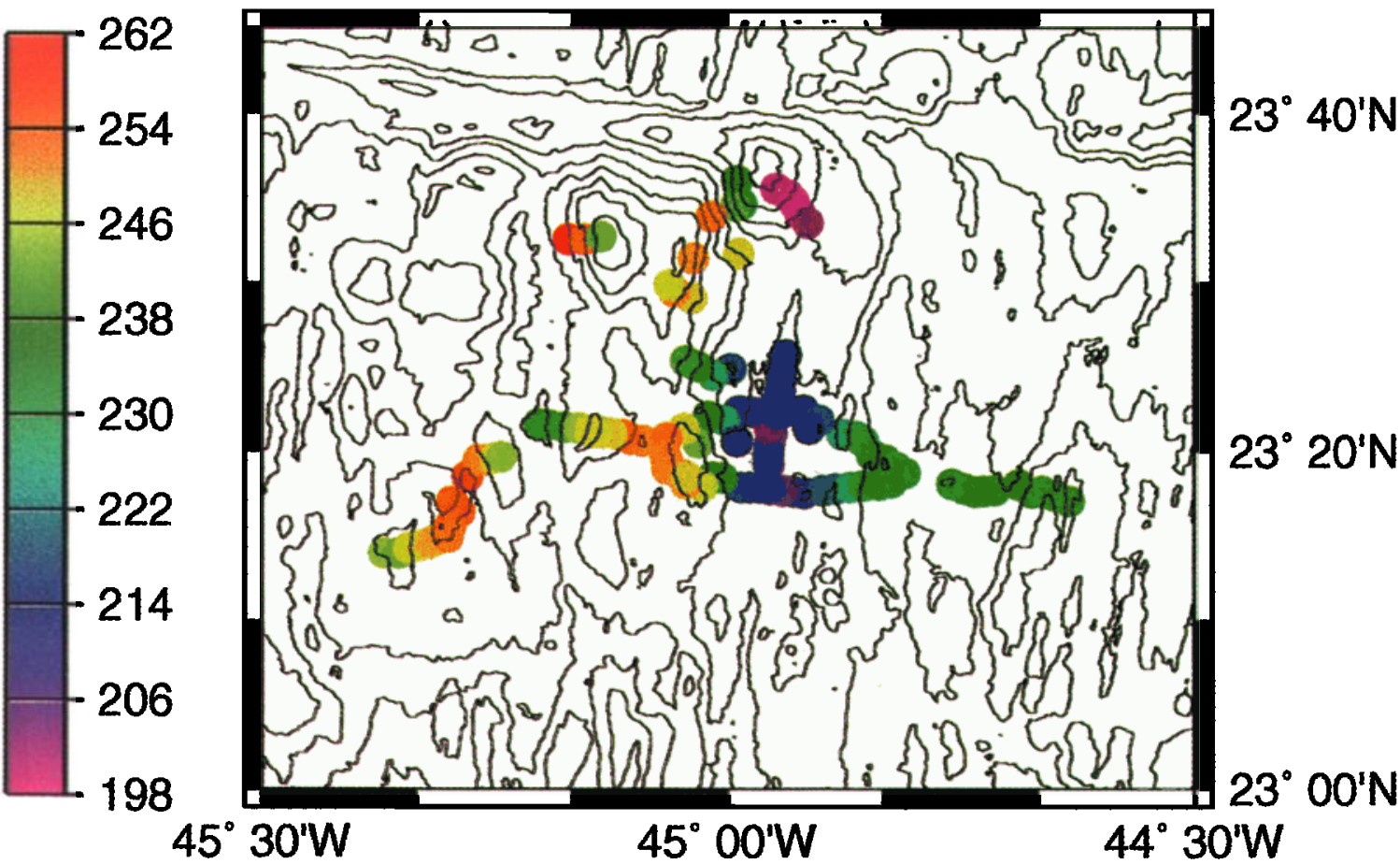

Plate 1. Bouguer anomalies calculated (top) at the sea surface and (bottom) on the seafloor. Isobaths are contoured every $500 \mathrm{~m}$. Both sets of Bouguer anomalies exhibit comparable features, with higher amplitudes on the sea bottom anomalies. Note the asymmetry between the two flanks of the ridge, Bouguer anomalies are lower on the east side, with smoother variations. 


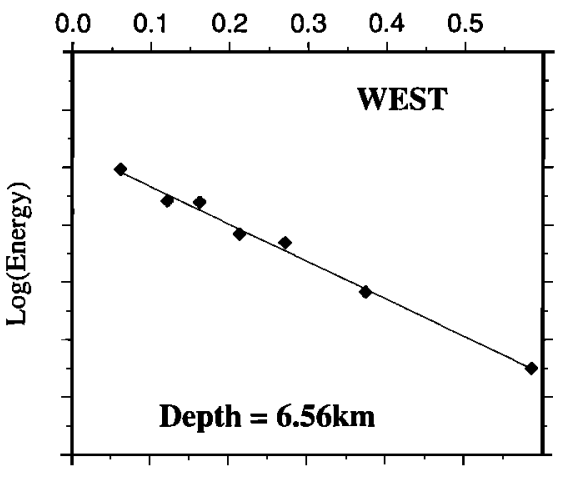

Wavenumber $\left(\mathrm{km}^{-1}\right)$

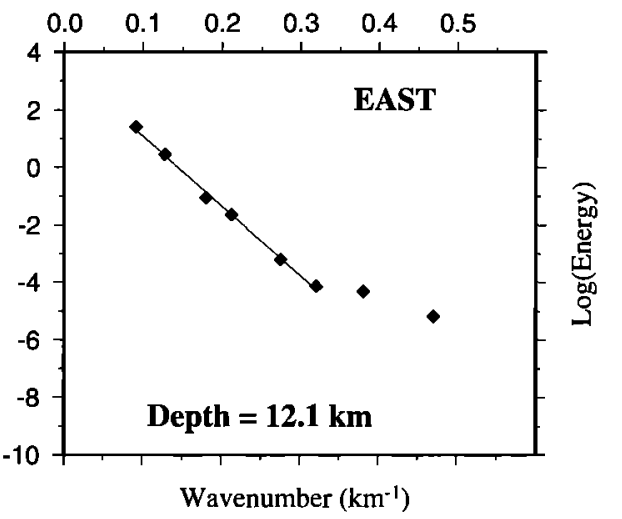

Figure 4. Comparative spectral analysis of the gravity field between east and west flanks of the ridge axis. If gravity sources are assumed to be statistically independent, the mean depth of the sources is obtained from the slope of the gravity spectrum in a logarithm diagram, with the energy logarithm versus the wavenumber. The results show that the mean depth of sources is deeper on the east side than on the west one $(12 \mathrm{~km}$ on the east versus $6.6 \mathrm{~km}$ on the west); this depth may represent the mean crust/mantle interface depth. Note that this spectral analysis suggests the fact that the asymmetry observed in the morphology is of deep origin.

both close to a major fracture zone and has a clearly asymmetric spreading rate, including, as previously mentioned, some small ridge axis jumps [Schulz et al., 1988]. In addition, for seafloor calculations, where isotherms of thermal models are closer to the measurements, any discrepancy in the direct model is amplified relative to the sea surface. Therefore we think that direct modeling for computing the regional signal is not an adequate solution for seafloor measurements in the MARK area.

We estimated the regional contribution on the surface data by filtering the sea surface Bouguer anomalies with a $100-\mathrm{km}$ cutoff wavelength cosine filter. The filtering method presents the disadvantage of removing any largewavelength crustal signal if there is one, as well as the contribution of any shorter-wavelength mantle structure. To remove regional contributions from the seafloor data that are generated by the same sources as in the sea surface data, we downward continued the surface regional field to $3 \mathrm{~km}$ depth. The difference between the regional signal on the sea surface and at depth ranges between 1 and $2 \mathrm{mGal}$.

In order to avoid edge effects on the study area, the regional anomaly has been computed on a large grid $\left(44^{\circ} / 47^{\circ} \mathrm{W}\right.$ and $\left.22^{\circ} / 24^{\circ} \mathrm{N}\right)$. The regional anomaly obtained displays a clear asymmetry, the east part being more negative than the west one. The residual Bouguer anomalies are computed from sea surface and seafloor Bouguer anomalies by subtracting this long-wavelength signal.

\subsection{Residual Seafloor and Sea Surface Bouguer Anomalies}

To a first order, gravity anomalies computed from the sea surface measurements and those computed from seafloor measurements are in agreement. To highlight the differences between the data sets, we extracted a profile of surface anomaly above the seafloor data location (Figure 5). Along this east-west profile, a strong negative anomaly is centered on the axial valley. The asymmetry previously noted can be observed in the residual Bouguer anomalies. Part of the crustal thickness difference and the thermal effect have been removed with the regional anomaly, but the crustal thickness difference remains as a contribution in the residual signal. On the west flank of the ridge axis, variations are similar in the two data sets, but amplitudes are of the order of $10 \mathrm{mGal}$ at the surface and $20 \mathrm{mGal}$ at the seafloor. On the east flank of the ridge, amplitudes are smaller (less than $10 \mathrm{mGal}$ on the seafloor), and variations are not identical at short wavelengths $(<10 \mathrm{~km})$ in both sets of data. The amplitude differences in the residual Bouguer anomalies between the flanks of the axis reflects an asymmetry in the inner crustal structure, superimposed on the differences of crustal thickness and thermal structure. The crust on the inside corner (west) of the axis appears more heterogeneous at the $10 \mathrm{~km}$ scale than the crust on the outside corner (east). In summary, gravity observations, added to geological evidence, demonstrate that a horizontal layered crustal model [cf. Penrose, 1972] cannot simply account for the observations on the west ridge flank in the MARK area. On the contrary, a layered crustal model cannot be disproved by observations on the east flank.

Along the studied profile, ultramafic outcrops have been recognized at two locations, one on the east flank of Pink Hill, where serpentinized peridotites have been described from submersible observations and then drilled, and one on the west flank of one off-axis hill, where peridotites have been described from submersible observations (dive GRN 12) and dredged (J. A. Karson, personal communication, 1996). In both cases, the associated gravity anomaly peak is shifted about 5-6 km westward with regard to the outcrops (Figure 5). On the east flank, no strong gravity anomaly was exhibited associated with the abyssal hills; it is likely that small Bouguer anomalies with short-tomedium wavelengths are caused by minor fault zones and petrological variations (metabasalts have been collected during dive GRN 6, and they are associated with a discrete negative anomaly superimposed on a positive medium wavelength anomaly).

\section{Modeling Residual Bouguer Anomalies \\ 6.1. Downward Continuation of the Sea Surface Map}

Knowledge of both sea surface and seafloor gravity measurements gives more information about the crustal 


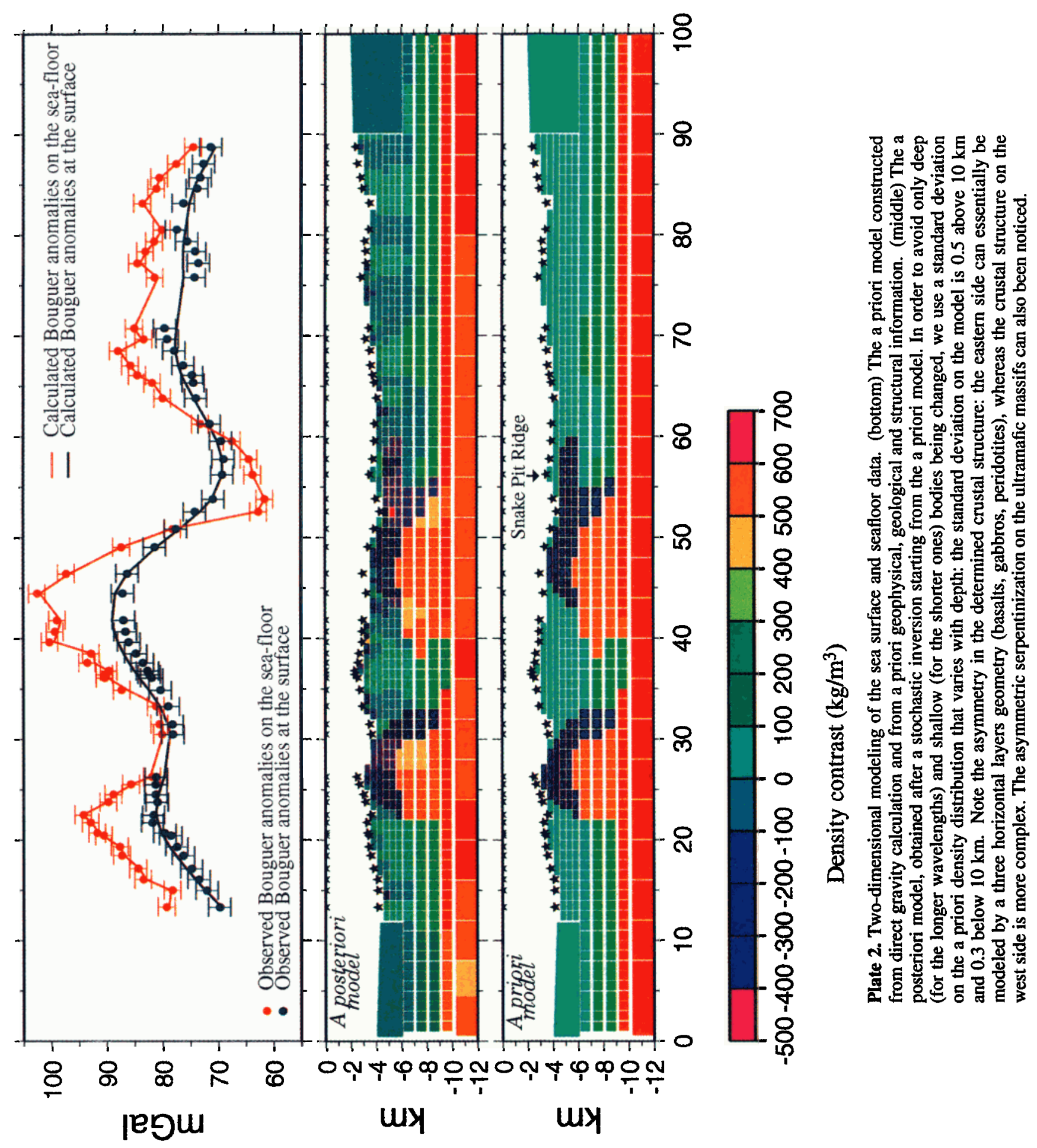



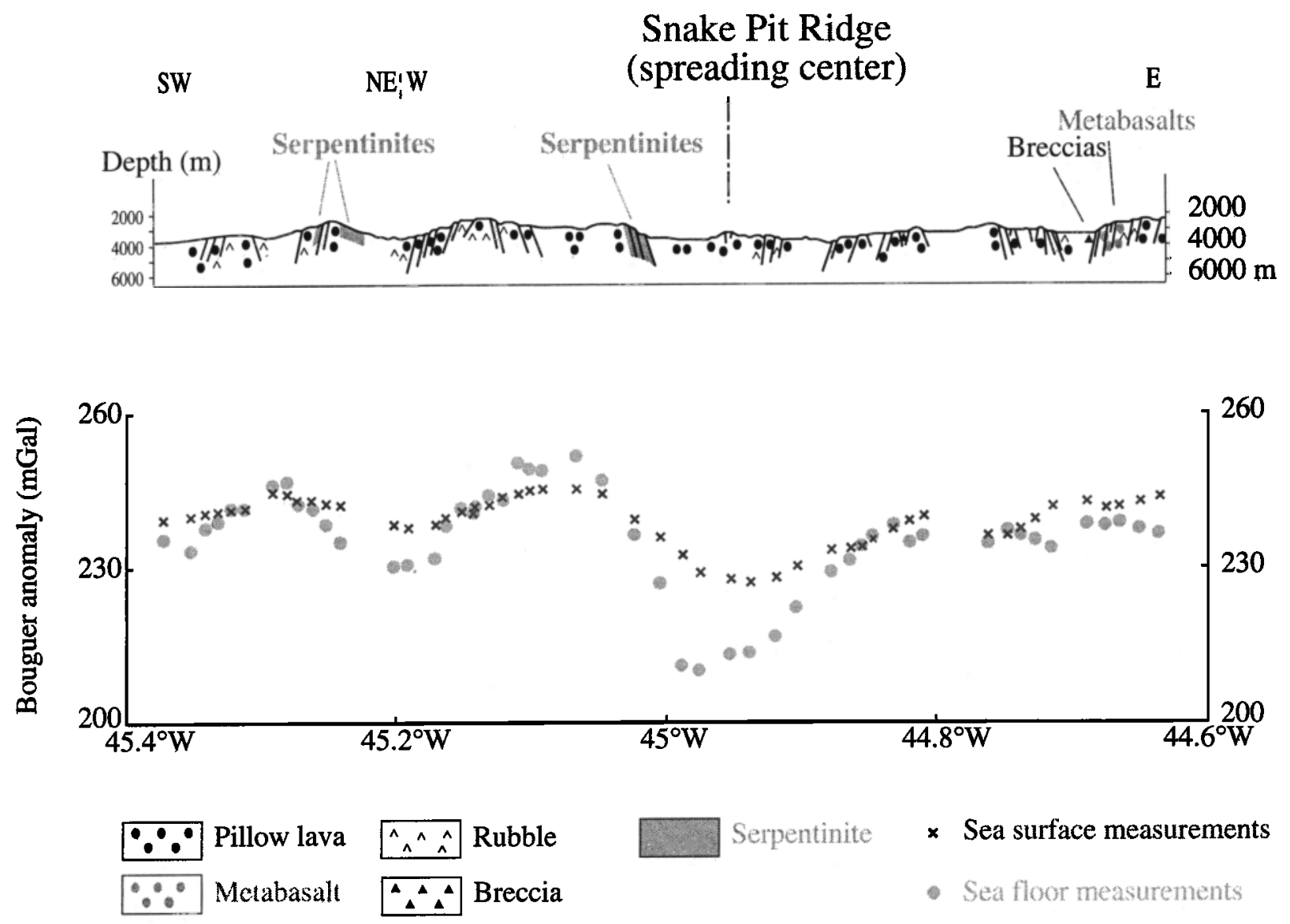

Figure 5. East-west profile across the ridge axis at the Snake Pit latitude (location in Figure 2). (top) A simplified geological and structural cross section. (bottom) The Bouguer anomalies computed along the profile on the sea surface and on the seafloor. The two hills where serpentinized peridotites have been collected are clearly associated with a positive anomaly around $20 \mathrm{mGal}$ amplitude. The maximum of the positive anomaly appears to be a least 5 $\mathrm{km}$ westward shifted with regards to the serpentinized peridotites outcrops.

densities distribution than if we had measurements at only a single level. The information we can derive from the gravity field at various altitudes is an indirect one, coming from the increased signal/noise ratio on the seafioor. At the sea surface, high-frequency signals have a low amplitude, within the measurement noise level and cannot therefore be recovered; the gravity signal collected on the sea surface is more sensitive to long-wavelength deeper sources. To investigate the relative information contained in both data sets, we downward continued the surface anomaly map to $3000 \mathrm{~m}$ depth. The downward continuation has been done using the algorithm of Gibert and Galdeano [1985], using a convolution product, to avoid several drawbacks of the FFT method [Gibert and Galdeano, 1985]. The continuation equation is based on the harmonic properties of potential fields outside the sources: the formulation is incorrect when there are sources between the initial data level and the continuation level. We low-pass-filtered the data with a cutting wavelength of $5 \mathrm{~km}$ in order to prevent instabilities in the continuation.

The continuation is performed in 3-D on the surface map (interpolated with Inoue's [1986] smoothing algorithm). Values are extracted from the downward continued map at the location of seafloor measurements. The comparison on an east/west profile (Figure 6) between the gravity field recorded on the seafloor and the one estimated by downward continuing the sea surface gravity shows a good agreement between the two sets of measurements. It may be due to the quantity and quality of the available marine gravity data and may not be the rule for less extensively surveyed areas. Beyond the first-order agreement, the results are not the same between the two flanks: on the east, there is no significant difference, and on the west, there is a shift of the positive anomaly located directly to the west of the axial valley. Keeping in mind the fundamental instability of downward continuation, we interpret this spatial offset as resulting from an eastward dip of the boundary between a deeper high-density body and a shallower lowdensity body. This interpretation is equivalent to saying that the high-frequency signal due to the boundary between dense and less dense bodies in the upper crust is lost in the surface data because of the poor signal/noise ratio and of the data processing. Beyond this, we previously observed that the positive gravity signature of mantle rocks outcrops is shifted 5-6 km west with regard to the serpentinized peridotites outcrops themselves [Karson et al., 1987; Mével et al., 1991; Durand et al., 1996]. These two observations lead us to propose that the mantle rock massif has been serpentinized in an asymmetric way: it is more altered on the east flank of the massif than on its west flank. 


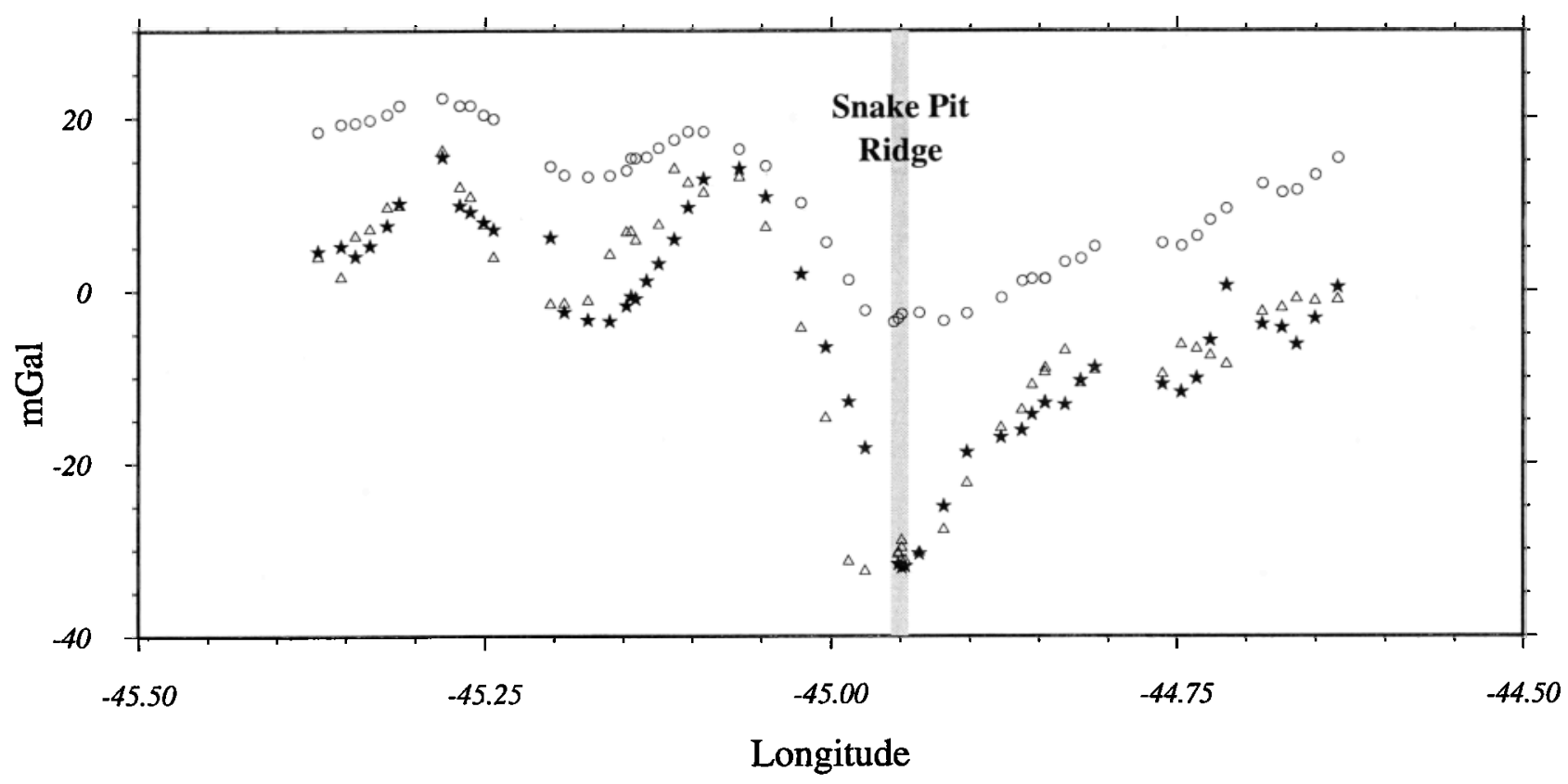

Figure 6. Comparison on the east/west profile, between Bouguer anomalies computed from seafioor measurements (triangles), computed from sea surface measurements (circles) and downward continued from surface measurements to a depth $3000 \mathrm{~m}$ (stars). The "measured" Bouguer anomaly on the sea surface results from an interpolation, above sea bottom data points. The downward continuation has been performed to a single level in order to avoid uncertainties introduced by the mixing of downward continued maps. The results show a good coherence between the Bouguer anomaly observed on the seafloor and the one obtained by downward continuing the sea surface measurements. The positive Bouguer anomaly related to the eastern ultramafic rock massif (Pink Hill) is shifted at least 1 $\mathrm{km}$ between the observed seafloor and the downward continued anomalies. The downward continuation is an unstable filter; the discrepancy may not be significant. However, we propose an interpretation where this eastward shift is an additional indication that the massif may be more serpentinized on its east flank and that the serpentinization boundary may.be oblique. In this interpretation, the center of mass of anomalous bodies is not located on the same vertical plane in the upper crust and in the lower crust. Such an obliquity results in shorter wavelength components of the signal being shifted with regard to the longer-wavelength components.

\subsection{A Priori Geological and Structural Knowledge}

A geological and structural analysis of this portion of the MARK area, mostly based on the video recordings of Gravinaute and Hydrosnake dives, has previously been performed [Durand et al., 1996]. We locate the main zones of crustal heterogeneities by their surface expressions and infer that a hot and high-porosity area is likely to be located beneath the neovolcanic ridge, considering its present-day magmatic and hydrothermal activity. Concerning ultramafic rocks outcrops, we assume that there is a spatial continuity between the outcrops and their deep source, which is equivalent to saying that serpentinized outcrops are not just isolated slivers.

\subsection{Direct Modeling}

To a first order and on the scale of this study, the ridge structure is two-dimensional. In fact, the bidimensional hypothesis is a good approximation for the east-west profile from dive GRN 6 to dive GRN 9; it is approximate for dives GRN 12-13-14 where the profile crosses the off-axis trace of the $23^{\circ} 15^{\prime} \mathrm{N}$ axial discontinuity. A 2-D direct model was constructed using Hypermag software [Saltus and Blakely, 1993]. We find a simple density distribution which both includes the constraints described above and creates a gravity field close to the one observed at the sur- face and on the seafloor (Plate 2). An improvement to the fit is found by inverting the data, as described in section 6.4. There is a range of possible models which can fit the data; for most of them, sea surface and seafloor data are fitted by deep and shallow sources, respectively. However, the number of models which fit the data is strongly decreased when shallow and deep sources are connected.

\subsection{Gravity Inversion}

Hussenoeder et al. [1995] recently pointed out that most current methods of potential field inversion require measurements to be reduced onto a unique level plane, resulting in a loss of resolution. On a magnetic profile example, they show how a direct inversion using the approximately equivalent geometry can better resolve fine-scale features characteristic of slow spreading ridges. The Monte Carlo type stochastic inversion technique, used in the present study, allows data inversion without first reducing them to a unique level [Bonvalot, 1995]. It also allows addition of a priori information [Tarantola and Valette, 1982a,b]. The inverse problem is solved using constraints from the data, the a priori parameters, and a theoretical relationship between the data and the parameters expressed by the Green's functions. We assume that the density probability functions representing the data, as 
well as the parameters, are Gaussian functions. Then, from Tarantola and Valette [1982a,b], the a posteriori state of knowledge $\sigma_{\rho}(P)$ can be written

$\sigma_{\mathrm{p}}(\mathbf{p})=\left[(2 \pi)^{\mathrm{NP}} \operatorname{det}\left(\mathrm{C}_{\mathrm{P}}\right)\right]^{-1 / 2} \exp \left[-\frac{1}{2}(\mathbf{p}-<\mathbf{p}>)^{\prime} \mathrm{C}_{\mathrm{P}}^{-1}(\mathbf{p}-<\mathbf{p}>)\right]$

where NP is the number of parameters, $C_{p}$ is the covariance matrix on the a posteriori parameters, and $\langle\mathbf{p}\rangle$ represents the mean value of parameters $p$, which are determined to maximize $\sigma_{\rho}(p)$. The unknown $\langle p\rangle$ and $C_{p}$ can be expressed as a function of the a priori information on the parameters $\mathbf{P}_{\text {prio }}$ and their a priori covariance $C_{p_{p o n}}$, the data $\mathbf{d}_{\text {obs }}$ and their associated covariance $C_{D}$, and the theoretical relationship between observations and model parameters $G$,

$$
\begin{gathered}
<p>=p_{\text {prior }}+C_{p_{p r o}} G^{t}\left[G C_{p_{p r o}} G^{t}+C_{D}\right]^{-1}\left[d_{o b s}-G p_{p r i o}\right] \\
C_{p}=C_{p_{p r o o}}-C_{p_{p r o o}} G^{t}\left[G C_{p_{p r o s}} G^{t}+C_{D}\right]^{-1} G_{p_{p r o o}}
\end{gathered}
$$

The a priori information on the parameters $\mathbf{p}_{\text {prio }}$ is derived from the direct modeling.

The forward model has been quantized in different size cells. Above $4.5 \mathrm{~km}$ below sea level and up to the bathymetry interface, the square cells have sides of $500 \mathrm{~m}$. Between $4.5 \mathrm{~km}$ and $6 \mathrm{~km}$, the cells are $1 \mathrm{~km}$ long and 500 $\mathrm{rn}$ wide, and between $6 \mathrm{~km}$ and $10 \mathrm{~km}$ below sea level, they are square with sides of $1 \mathrm{~km}$. Below $10 \mathrm{~km}$, down to the bottom limit of the model at $12 \mathrm{~km}$, there is only one layer of $4 \mathrm{~km}$ square cells.

Plate 2 shows the inversion result for an a priori model in which the standard deviation on the density distribution is $300 \mathrm{~kg} / \mathrm{m}^{3}$ above $10 \mathrm{~km}$ and $100 \mathrm{~kg} / \mathrm{m}^{3}$ below $10 \mathrm{~km}$, and the standard deviation on the gravity data is 1.5 and $2 \mathrm{mGal}$ for seafloor and sea surface measurements, respectively. The resulting model is sensitive to the starting one, although in our case, this sensitivity arises primarily from the standard deviation assigned to the different cells in the starting model. When the standard deviation is uniform, the inversion tends to accommodate the two levels of measurements by different sources: sea surface variations are accommodated by the deep cells and seafloor anomalies are adjusted by modifying the uppermost layer of cells. In our final model, we tried to prevent this effect by reducing the standard deviation at depth so the sea surface anomalies would also be accommodated by midcrustal sources and not only deep ones.

\subsection{Resulting Gravity Model}

Plate 2 shows the model obtained after the inversion. The main characteristic highlighted by this model is the fundamental difference between the two sides of the ridge axis. The crustal structure obtained on the east side is close to a simple three-layer crust. On the west side, the inverse model shows that the crustal architecture is more complex, with two positive density contrast massifs bordered by less dense material especially on the east side. Even if part of the crustal thickness difference between the two sides of the ridge has been removed with the regional signal, the model still shows that the mantle/crust interface is deeper or that the averaged density of the crust is lower on the east side than on the westside. The geometry of the crustal structure we obtain also shows that a low-density body is required to explain the short-wavelength negative Bouguer anomaly observed at the ridge axis.

\section{Discussion and Geological Implications}

\subsection{Is There an Axial Magma Chamber?}

The gravity data inversion we performed at the Snake Pit site (Plate 2) shows that a low-density zone, with a reduced density of around $300 \mathrm{~kg} / \mathrm{m}^{3}$, is located beneath the axial valley at a shallow depth; this low- density body can be attributed, at least partly, either to a magmatic body or to a hydrothermally altered fault zone. Although there is no general agreement on the possible density contrast associated with silicate melts relative to the residual solids (peridotites), values found in the literature range from 300 to $500 \mathrm{~kg} / \mathrm{m}^{3}$ [Niu and Batiza, 1991]. The gravity inverse solution revealed that a negative density contrast up to 300 $\mathrm{kg} / \mathrm{m}^{3}$, relative to the surrounding basalts, can explain the observed anomalies.

The magnitude of the low-density body modeled beneath the ridge axis is highly dependent on estimation of the regional trend due to the lithospheric cooling away from the axis. The thermal contribution probably contains more short wavelengths, associated with rapid initial thickening, close to the axis. The filter cutoff of $100 \mathrm{~km}$ that was used in the regional trend withdrawal is convenient but may be too large at the axis. The negative residual found in the axial valley may be thus partly explained by an inadequate estimation of the thermal cooling of the lithosphere. Aside from reservations about the actual density contrast, our data suggest the presence of a low-density body beneath the Snake Pit neovolcanic ridge. This low-density body could, at least in part, correspond to a crustal magma chamber. However, we think that the negative density required to account for the anomaly is too high to be only due to a magma chamber. Thus we think, in agreement with Luyen$d y k$ [1984] on the East Pacific Rise, that this negative density contrast instead corresponds to a fractured crust filled with heated seawater or to a combination of both effects.

\subsection{Origin of Off-Axis Abyssal Hills}

Structural analysis of off-axis hills in the MARK area [Durand et al., 1996] suggests a horst and graben organization in the tectonic expression. However, the detailed gravity study clearly points out that different off-axis hills may have distinct origins. Submersible observations conducted during the Gravinaute cruise show that the west flank of the hill explored during dives GRN 8 and GRN 9 (Figure 2) is at least in part magmatically built [Durand et al., 1996] ; this massif is interpreted as a possible old neovolcanic ridge produced by a ridge axis jump. Such jumps have been documented close to the area [Schulz et al., 1988]. The gravity profile over this hill shows that the crust is neither thin nor thick beneath it. Considering the relatively fresh basalt lava flows deepening on both flanks of the hill [Durand et al., 1996] and referring to the gravity signature, we propose that this abyssal hill is inherited from an ancient neovolcanic ridge. The presence of past hydrothermal activity and a negative Bouguer anomaly on the seafloor at the top of Hydrosnake dive HS16, in the continuation of the studied elongated hill (Figure 2), further supports this interpretation. 
Concerning the westernmost hill (dive GRN12), where both flanks show serpentinized peridotites [Durand et al., 1996], the positive gravity anomaly, thought to be related to the crustal thinning, is shifted at least $6 \mathrm{~km}$ to the west with respect to the hill summit. In this region, the ridge is far from being a two-dimensional structure, and interpretation should consider the three-dimensional features revealed by the surface gravity anomaly map and the structural analysis. Dive GRN 14, which explored the flank of this abyssal hill farther south, and its transition into the $23^{\circ} 15^{\prime} \mathrm{N}$ discontinuity off-axis trace, revealed that the main fault trends southeast, perpendicular to the dive tracks in this part of the profile. The downward continued anomaly profile (Figure 6) does not exhibit the same shift with regards to the seafloor observations, as on Pink Hill; we propose that this difference comes from an asymmetrical serpentinization, not only between the west and east flanks but also between the south and north flanks. The east flank of the ridge axis (dives GRN2 to GRN6) exhibits variations in the Bouguer anomaly of smaller amplitude than the west flank. Our data do not show a clear gravity signature associated with the three off-axis hills explored during the Gravinaute cruise (dives GRN2-4, GRN5, and GRN6).

\subsection{Outcropping of Mantle Rocks}

As evidenced by the good correlation between the positive gravity anomalies near the end of segments and the outcrops of ultramafic rocks, the outcropping mechanism is interpred to be related to the $20-100 \mathrm{~km}$ segmentation of the ridre axis [Cannat et al., 1994; Tucholke and Lin, 1994; Cannat et al., 1995; Durand, 1996; Durand et al., 1996]. In addition, Tucholke and Lin [1994] and Escartin and Lin [1995] have documented that in most cases the positive anomaly is associated with the inside corner of slow spreading crust and not with the outside corner crust.

The question of mantle rock massif structure can be addressed from cross-sectional profiles, as we do in the present paper, and also from along-axis profiles across segment discontinuities. On the Mid-Atlantic Ridge between latitude $28^{\circ} \mathrm{N}$ and $31^{\circ} 30^{\prime} \mathrm{N}$, Rommevaux et al, [1994] describe a systematic shift of about $10 \mathrm{~km}$ between transform and nontransform axial discontinuity signatures identified from bathymetric depressions and from positive Bouguer anomalies: the gravity signal is shifted, with regard to the bathymetric signal, toward the north on the west side of the ridge axis and toward the south on the other side. The along-axis morphology of segment discontinuities is not symmetric, the offset direction being responsible for the asymmetry in a way similar to the inside/outside corner geometry of a fracture zone [Sloan and Patriat, 1992; Durand, 1996]. The systematic shift is interpreted to result from the block-tilting along the discontinuity [Rommevaux, 1994; Rommevaux et al., 1994]. An asymmetric serpentinization related to faults may also be responsible for part of the shift induced by the asymmetric structure of the crustal thinning at segment discontinuities.

\section{Conclusion}

The analysis of seafloor and sea surface gravity anomalies allows us to propose a model for the crustal structure in the MARK area, at the Snake Pit latitude. If the long-wavelength bathymetric features are solely related to the lithospheric structure (subsidence away from the axis or thickening of the crust beneath the east part of the rift valley associated with a dynamically supported deeper bathymetry), the shorter-wavelength features, such as the different small hills, are interpreted to reflect varied phenomena such as tectonic expression of the spreading or magmatic construction.

Geological and structural analyses provide constraints on the surface expression of deep mechanisms but do not fully explain the inner structure of the crust. The structural expression is not very different from one abyssal hill to another; however, the fine-scale gravity study shows that their origin and their significance may be quite different. Many models have been proposed to explain the formation of abyssal hills; two end-members are the tectonic model proposed, for example, by Macdonald and Atwater [1978] or Mutter and Karson [1992] and the magmatic construction model proposed by Vogt et al. [1969]. According to our interpretation, the MARK area exhibits at least one hill of each type: the two hills, where serpentinized peridotites are exposed, have been constructed through an asymmetric tectonic process (occurring probably on a crust with an already thin magmatic layer), and the hill where only basaltic rocks are exposed (dive GRN 8-9) has been, at least in part, magmatically built.

The characterization of magma bodies at the ridge axis is a still highly debated question. We cannot settle the debate: our inverse solution indicates the presence of a low-density body $\left(\Delta p \sim-300 \mathrm{~kg} / \mathrm{m}^{3}\right)$ beneath the Snake Pit neovolcanic ridge. This low-density body could result from a magma chamber, a highly hydrothermally fractured fault zone, or a combination of both.

One of the most striking feature observed in the seafloor and sea surface gravity field in the MARK area is the fundamental asymmetry across the axis, which is also seen in bathymetric and magnetic data. This asymmetry seems to be related to amagmatic periods of spreading and is accomplished, at least partly, through low-angle normal faulting (around $45^{\circ} \mathrm{dip}$, according to the gravity direct and forward modeling). The Kane Fracture Zone and the inside/outside corner geometry may control the direction of fault dips and may be responsible for the strong asymmetry in the sense that faults deepen always toward the east.

Detailed constraints on the fine-scale crustal structure provided by seafloor gravity data, in conjunction with extensive sea surface data, have brought new insights on accretion mechanisms at a slow spreading ridge. Such results could not have been obtained from sea surface data alone, and thus our study shows the usefulness of collecting data close to the seafloor and comparing potential field values collected at different altitudes. The high cost of seafloor gravity data acquisition results in a small number of measurements, and the ability of the technique to observe high-frequency signals is limited by the spacing of the data collected. Future seafloor gravity experiments would benefit from a denser survey coverage, which could be obtained using a continuously sampling instrument operated close to the sea bottom.

Acknowledgments. The manuscript was greatly improved by the thoughtful reviews of D. Blackman, J. A. Hildebrand, J. Lin, P. Johnson, and J. Phipps Morgan. We are also grateful to C. Durand, C. Rommevaux, P. Gente, and M. Cannat for many discussions. We would like to thank 
Captain R. Derouet, the crew of the R/V Nadir and the Nautile team, who all contributed to the success of Gravinaute cruise, and the scientific party who did the measurements. Most of the figures were performed using the GMT software package [Wessel and Smith, 1991]. B. Kennedy prepared the typescript. IPGP contribution 1505.

\section{References}

Aumento, F., and H. Loubat, The Mid-Atlantic Ridge near $45^{\circ} \mathrm{N}$, XVI, Serpentinized ultramafic intrusions, Can. J. Earth Sci., 8, 631-663, 1971.

Auzende, J.M., M. Cannat, P. Gente, J.P. Henriet, T. Juteau, J.A. Karson, Y. Lagabrielle, C. Mével, and $M$. Tivey, Affleurements de roches profondes de la croute océanique et du manteau sur le mur sud de la zone de fracture Kane (Atlantique central): Observations par submersible, $C$. R. Acad. Sci., Ser. II, 3I7, 1641-1648, 1993.

Blackman, D.K., and D.W. Forsyth, Isostatic compensation of tectonic features of the Mid-Atlantic Ridge: $25^{\circ}-27^{\circ} 30^{\prime}$ S, J. Geophys. Res., 96 , $11,741-11,758,1991$.

Bonatti, E., and J. Honnorez, Sections of Earth's crust in the equatorial Atlantic, J. Geophys. Res., 8I, 4104-4116, 1976.

Bonvalot, S., IMC2-G: Programme d'inversion moindres carres 2D en gravimétrie pour station de travail (SUN/OS 4.1.3), rapport Interne, Lab. de Géophys., ORSTOM, Bondy, France, 1995.

Bowin, C.E., S.L. Ryland, T. Simkin, and K.A. Howard, Depth estimates from ratios of gravity, geoid and gravity gradient anomalies, Geophysics, 51, 123-136, 1986.

Calvert, A.J., Seismic evidence for a magma chamber beneath the slowspreading Mid-Atlantic Ridge, Nature, 377, 410-414, 1995.

Cannat, M., Emplacement of mantle rocks in the seafloor at mid-ocean ridge, J. Geophys. Res., 98, 4163-4172, 1993.

Cannat, M., T. Juteau, and E. Berger, Petrostructural analysis of the Leg 109 serpentinized peridotites, Proc. Ocean Drill. Program, Sci. Results, 106/109, 47-56, 1990.

Cannat, M., C. Mével, and Shipboard Party of the Seadma II Cruise, FARA: Along-axis and across-axis sampling of the crust at the MidAtlantic Ridge $: 20^{\circ} \mathrm{N}-24^{\circ} \mathrm{N}$, InterRidge News, 3(1), 13-18, 1994.

Cannat, M., et al., Thin crust, ultramafic exposures, and rugged faulting patterns at the Mid-Atlantic Ridge ( $\left.22^{\circ}-24^{\circ} \mathrm{N}\right)$, Geology, 23 (1), 49-52, 1995.

Caress, D.W., M.S. Burnett, and J.A. Orcutt, Tomographic image of the axial low-velocity zone at $12^{\circ} 50^{\prime} \mathrm{N}$ on the East Pacific Rise, J. Geophys. Res., 97, 9243-9263, 1992.

Carlson, R.L., and C.N. Herrick, Densities and porosities in the oceanic crust and their variations with depth and age, J. Geophys. Res., 95, 9153-9170, 1990.

Christensen, N.I., and M.H. Salisbury, Structure and constitution of the lower oceanic crust, Rev. Geophys., 13(1), 57-86, 1975.

Crane, K., The spacing of rift axis highs: Dependence upon diapiric processes in the underlying asthenosphere, Earth Planet. Sci. Lett., 72, 405-414, 1985.

Deplus, C., M. Maia, D. Aslanian, and P. Gente, Segmentation of the Mid-Atlantic Ridge south of Kane Fracture Zone revealed by gravity anomalies--Results of SEADMA I cruise, Eos Trans. AGU, 73, 568, 1992.

Detrick, R.S., P.J. Fox, K.A. Kastens, W.B.F. Ryan, L. Mayer, and J.A. Karson, Sea Beam survey of the Kane fracture zone and the adjacent Mid-Atlantic Ridge valley, Eos Trans AGU, 65, 1006, 1984.

Detrick, R.S., P. Buhl, J. Mutter, J. Orcutt, T. Brocker, and J. Madsen, Multichannel seismic imaging of the axial magma chamber along the East Pacific Rise between $9^{\circ}$ and $13^{\circ} \mathrm{N}$, in Eos Trans AGU, 67, 360, 1986.

Detrick, R.S., P. Buhl, E. Vera, J. Mutter, J. Orcutt, J. Madsen, and T. Brocker, Multichannel seismic imaging of an axial magma chamber along the East Pacific Rise between $9^{\circ} \mathrm{N}$ and $13^{\circ} \mathrm{N}$, Nature, 326, 35-41, 1987.

Detrick, R.S., J.C. Mutter, P. Buhl, and I.I. Kim, No evidence from multichannel reflection data for a crustal magma chamber in the MARK area on the Mid-Atlantic Ridge, Nature, 347, 61-64, 1990.
Detrick, R.S., H.D. Needham, and V. Renard, Gravity anomalies and crustal thickness variations along the Mid-atlantic ridge between $33^{\circ} \mathrm{N}$ and 40, J.Geophys. Res., 100, 3767-3787, 1995.

Dick, H.J.B., Abyssal peridotites, very slow spreading ridges and ocean ridge magmatism, in Magmatism in the Ocean Basins, edited by A.D. Saunders and M.J. Norry, 71-105, Geol. Soc. Spec. Publ. Oxford 42, 71-105, 1989.

Dick, H.J.B., W.B. Bryan, and G. Thompson, Low-angle faulting and steady-state emplacement of plutonic rocks at ridge-transform intersections, Eos Trans AGU, 62, 406, 1981.

Dubois, J., and C. Deplus, Gravimetry on the Erimo Seamount, Japan, Tectonophysics, 160, 267-275, 1989.

Dubois, J., C. Deplus, C. Mével, J.P. Berges, and M. Diament, Sea-bottom gravity measurements in the MARK area, First results, Eos Trans. $A G U, 73,568,1992$.

Dubois, J., et al., The Gravinaute cruise: Seafloor gravity and electromagnetism at the MARK-Snake Pit area, InterRidge News, 3(I), 3-6, 1994.

Durand, C., Segmentation d'une dorsale á faible taux d'expansion: Evolution de la dorsale médio-atlantique au sud de la zone de fracture Kane $\left(20^{\circ} \mathrm{N}-24^{\circ} \mathrm{N}\right)$ depuis $10 \mathrm{MA}$, doctorat thesis, Univ. de Bretagne Occidentale, Brest, France, 1996.

Durand, C., V. Ballu, P. Gente, and J. Dubois, Horst and graben structures on the flanks of the Mid-Atlantic Ridge in the MARK area $\left(23^{\circ} 22^{\prime} \mathrm{N}\right)$ : Submersible observations, Tectonophysics, 265, 275-297, 1996.

Escartin, J. and J. Lin, Ridge offsets, normal faulting and gravity anomalies of slow spreading ridges, J. Geophys. Res., 100, 6163-6177, 1995.

Francheteau, J., and R.D. Ballard, The East Pacific Rise near $21^{\circ} \mathrm{N}, 13^{\circ} \mathrm{N}$ and $20^{\circ} \mathrm{S}$ : Interferences of along-strike variability of axial processes of mid-ocean ridge, Earth Planet. Sci. Lett., 64, 93-116, 1983.

Francis, T.J.G., Serpentinization faults and their role in the tectonics of slow spreading ridges, J. Geophys. Res., 86, 11,616-11,622, 1981.

Gente, P., Etude morphostructurale comparative de dorsales océaniques à taux d'expansion variés, doctorat thesis, Univ. de Bretagne Occidentale, Brest, France, 1987.

Gente, P., et al., Geometry of past and present-day segmentation of the Mid-Atlantic ridge south of Kane fracture zone, in Eos Trans. AGU, 72, Fall Meet. Suppl., 477, 1991a.

Gente, P., C. Mével, J.M. Auzende, J.A. Karson, and Y. Fouquet, An example of a recent accretion on the Mid-Atlantic Ridge: The Snake Pit neovolcanic ridge (MARK area, $23^{\circ} 22^{\prime} \mathrm{N}$ ), Tectonophysics, 190, 1-29, 199lb.

Gente, P., L.P. Zonenshain, M.I. Kuzmin, A.P. Lisitsin, Y.A. Bogdanov, and B.V. Baranov, Géologie de l'axe de la dorsale médio-atlantique entre $23^{\circ} \mathrm{N}$ et $26^{\circ} \mathrm{N}$ : Résultats preliminaires de la campagne du N/O Akademik Mstislav Keldysh (mars-avril 1988), C. R. Acad. Sci., Ser. II, 308, 1781-1788, 1989.

Gibert, D., and A. Galdeano, A computer program to perform transformations of gravimetric and aeromagnetic surveys, Comp. Geosci. II(5), 553-588, 1985.

Hahn, A., E.G. Kind, and D.C. Mishra, Depth calculation of magnetic sources by means of Fourier amplitude spectra, Geophys. prosp., 24, 287-308, 1976.

Hale, L.D., C.J. Morton, and N.H. Sleep, Reinterpretation of seismic reflection data over the East Pacific Rise, J. Geophys. Res., 87, 7707$7717,1982$.

Harrison, G.C.A., Tectonics of mid-ocean ridges, Tectonophysics, 22, 301-310, 1974.

Heiskanen, W.A., and F.A. Vening Meinesz, The Earth and Its Gravity Field, Mc Graw-Hill, Geol. Sciences Ser., New York, 1958.

Herron, T.J., W.J. Ludwig, P.L. Stoffa, T.K. Kan, and P. Buhl, Structure of the East Pacific Rise from multichannel seismic reflection data, $J$. Geophys. Res., 83, 798-804, 1978.

Herron, T.J., P.L. Stoffa and P. Buhl, Magma Chamber and mantle reflections, East Pacific Rise, Geophys. Res. Lett., 7, 989-992, 1980.

Hildebrand, J.A., J.M. Stevenson, T.C. Hammer, M.A. Zumberge, and R.L. Parker, A seafloor and sea surface gravity survey of Axial volcano, J. Geophys. Res., 95, 12,751-12,763, 1990. 
Holmes, M.L., and H.P. Johnson, Upper crustal densities derived from sea-floor gravity measurements: Northern Juan de Fuca ridge, Geophys. Res. Lett., 20, report, 1871-1874, 1993.

Hugill, A., The design of a gravimeter with automatic readout, report, Univ. of South Australia, Flinders, 1984.

Hussenoeder, S.A., M.A. Tivey, and H. Schouten, Direct inversion of potential fields from an uneven track with application to the MidAtlantic Ridge, Geophys. Res. Lett., 22, 3131-3134, 1995.

Inoue, H., A least-squares smooth fitting for irregularly spaced data: Finite-element approach using the cubic B-spline basis, Geophysics, 51, 2051-2060, 1986

Juteau, T., M. Cannat, and Y. Lagabrielle, Serpentinized peridotites in the upper oceanic crust away from transform zones: A comparison of the results of previous DSDP and ODP legs, Proc. Ocean Drill. Program., Sci. Results, 106/109, 303-308, 1990.

Kappel, E.S., and W.B.F. Ryan, Volcanic episodicity and a non-steady state rift valley along northeast Pacific spreading centers: Evidence from Sea MARK I, J. Geophys. Res., 91, 13,925-13,940, 1986.

Karson, J.A., Seafloor spreading on the Mid-Atlantic Ridge: Implications for the structure of ophiolites and oceanic lithosphere produced in slow-spreading environments, in Proceeding of the Symposium "TRODOS 1987", edited by J. Malpas, E.M. Moores, A. Panayiotou, and C. Xenophontos, Geological Survey Department, Nicosia, Cyprus, 547$555,1990$.

Karson, J.A., and H.J.B. Dick, Tectonics of ridge-transform intersections at the Kane fracture zone, Mar. Geophys. Res., 6, 51-98, 1983.

Karson, J.A., and P.A. Rona, Block-tilting, transfer faults, and structural control of magmatic and hydrothermal processes in the TAG area, Mid-Atlantic ridge 26² , Geol. Soc. Am. Bull., 102, 1635-1645, 1990.

Karson, J.A., et al., Along-axis variations in seafloor spreading in the MARK area, Nature, 328, 681-685, 1987.

Kent, G.M., A.J. Harding, and J.A. Orcutt, Evidence for a smaller magma chamber beneath the East Pacific Rise at $9^{\circ} 30^{\prime} \mathrm{N}$, Nature, 344, 650-653, 1990.

Kuo, B.Y., and D.W. Forsyth, Gravity anomalies of the ridge-transform system in the South Atlantic between 31 and $34.5^{\circ} \mathrm{S}$ : Upwelling centers and variations in the crustal thickness, Mar. Geophys. Res., 10, 205$232,1988$.

Leg 109 Scientific Party, Coring the crust and the mantle, Nature, 323, 492-493, 1986.

Leg 109 Shipboard Scientific Party, Site 670, Proc. Ocean Drill. Program, Initial Rep., 109, 203-237, 1988.

Lin, J., and J. Phipps Morgan, The spreading rate dependence of threedimensional Mid-Atlantic Ridge gravity structure, Geophys. Res. Lett., 19, 13-16, 1992.

Lin, J., G.M. Purdy, H. Shouten, J.-C. Sempere, and C. Zervas, Evidence from gravity data for focused magmatic accretion along the MidAtlantic Ridge, Nature, 344, 627-632, 1990.

Longman, I.M., Formulas for computing the tidal acceleration due to the Moon and the Sun, J. Geophys. Res., 64, 2351-2355, 1959.

Luyendyk, B.P., On-bottom gravity profile across the East Pacific Rise crest at $21^{\circ}$ north, Geophysics, 49, 2166-2177, 1984.

Macdonald, K.C., and T. Atwater, Evolution of rifted ocean ridges, Earth Planet. Sci. Lett. 39, 319-327, 1978.

Macdonald, K.C., and B.P. Luyendyk, Deep-tow studies of the structure of the Mid-Atlantic Ridge crest near latitude $37^{\circ} \mathrm{N}$, Geol. Soc. Am. Bull., 88, 621-636, 1977.

Macdonald, K.C., P.J. Fox, R.T. Alexander, R. Pockalny, and P. Gente, Volcanic growth faults and the origin of Pacific abyssal hills, Nature, 380, 125-129, 1996.

Maia, M., and P. Gente, Three-dimensional gravity and bathymetry analysis of the Mid-Atlantic Ridge between 20 and $24^{\circ} \mathrm{N}$ : Flow geometry and temporal evolution of the segmentation, J. Geophys. Res., in press, 1997.

Malinverno, A., and R.A. Pockalny, Abyssal hill topography as an indicator of episodicity in crustal accretion and deformation, Earth Planet. Sci. Lett. 99, 154-169, 1990.

Mével, C., et al., La ride du Snake Pit (dorsale médio-Atlantique, $23^{\circ} 22^{\prime} \mathrm{N}$ ) : résultats preliminaires de la campagne HYDROSNAKE, $C$. R. Acad. Sci., 308, Ser. II, 545-552, 1989.
Mével, C., M. Cannat, P. Gente, E. Marion, J.M. Auzende, and J.A. Karson, Emplacement of deep crustal and mantle rocks on the west median valley wall of the MARK area (MAR, $23^{\circ} \mathrm{N}$ ), Tectonophysics, $190,31-$ $53,1991$.

Milson, J., Field Geophysics, Geol. Soc. London Hand., 182 pp., John Wiley, New York, 1989.

Morris, E., and R.S. Detrick, Three-dimensional analysis of gravity anomalies in the MARK area, Mid-Atlantic Ridge $23^{\circ} \mathrm{N}, J$. Geophys. Res., 96, 4355-4366, 1991.

Morris, E., R.S. Detrick, and B.Y. Kuo, Three-dimensional analysis of gravity anomalies in the MARK area, Mid-Atlantic Ridge $23^{\circ} \mathrm{N}$, Eos Trans. AGU, 70, 1326, 1989.

Morton, J.L., and N.H. Sleep, Seismic reflections from a Lau Basin magma chamber, in Geology and Offshore Resources of Pacific Island Arcs-Tonga Region, edited by D.W. Scholl and T.L. Vallier, pp. 441453, Houston, Tex, 1985.

Mutter, J.C., and J.A. Karson, Structural processes at slow-spreading ridges, Science, 257, 627- 634, 1992.

Mutter, J.C., R.S. Detrick, and The NAT Study Group, Multichannel seismic evidence for anomalously thin crust at oceanic fracture zones, Geology, 12, 534-537, 1984.

Needham, H.D., M. Voisset, V. Renard, H. Bougault, O. Dauteuil, R. Detrick, and $C$. Langmuir, Structural and volcanic features of the MidAtlantic Rift Zone between $40^{\circ} \mathrm{N}$ and $33^{\circ} \mathrm{N}$ (abstract), Eos Trans. $A G U$. 73(43), Fall Meet Suppl., 552, 1992.

Nettleton, L.L., Gravity and Magnetics in Oil Prospecting, Mc Graw-Hill, New York, 1976.

Nicholls, G.D., A.J. Nalwalk, and E.E. Hays, The nature and composition of rock samples dredged from the Mid-Atlantic Ridge between $22^{\circ} \mathrm{N}$ and $52^{\circ} \mathrm{N}$, Mar. Geol., 1, 333-343, 1964.

Niu, Y., and R. Batiza, Denscal: A program for calculating densities of silicate melts and mantle minerals as a function of pressure, temperature, and composition in melting range, Comput. Geosci., 17(5), 679-687, 1991.

Osmaston, M.F., Genesis of ocean ridge median valleys and continental rift valleys, Tectonophysics, 11, 387-404, 1971.

Parasnis, D. S., Principles of Applied Geophysics, Methuen, London, 1962.

Parker, R. L., Improved terrain correction: part II, Geophysics, 61, 365372, 1996.

Parsons, B., and J.G. Sclater, An analysis of the variation of ocean floor bathymetry and heat flow with age, J. Geophys. Res., 82, 803-827, 1977.

Penrose, Penrose conference on ophiolites, Geotimes, 17, 24-25, 1972.

Phipps Morgan, J., and D.W. Forsyth, 3-D flow and temperature perturbations due to a transform offset: Effects on oceanic crustal and upper mantle structure, J. Geophys. Res., 93, 2955-2966, 1988.

Poudjom Djomani, Y.H., Apport de la gravimétrie à l'étude de la lithosphère continentale et implications geodynamiques. Etude d'un bombement intra-plaque: Le massif de l'Adamaoua (Cameroun), doctorat thesis, Univ. de Paris Sud, Orsay, France, 1993.

Poudjom Djomani, Y.H., J.M. Nnange, M. Diament, C.J. Ebinger, and J.D. Fairhead, Effective elastic thickness and crustal thickness variations in west Africa inferred from gravity data, J. Geophys. Res., 100, 22047-22070, 1995.

Purdy, G.M., and R.S. Detrick, Crustal structure of the Mid-Atlantic Ridge at $23^{\circ} \mathrm{N}$ from seismic refraction studies, J. Geophys. Res., 91, 3739$3762,1986$.

Rommevaux, C., Etude gravimétrique et magnétique de l'évolution de la segmentation des dorsales lentes, doctorat thesis, Univ. Paris VII, Paris, 1994.

Rommevaux, C., C. Deplus, P. Patriat, and J.C. Sempere, Threedimensional gravity study of the Mid-Atlantic Ridge: Evolution of the segmentation between $28^{\circ}$ and $29^{\circ} \mathrm{N}$ during the last $10 \mathrm{Myr}, J$. Geophys. Res., 99, 3015-3029, 1994.

Saltus, R.W., and R.J. Blakely, Hypermag: an interactive 2 and 2.5 dimensional gravity and magnetic modeling program, version 3.5 , U.S. Geol.Surv., Denver, Colorado; U.S. Dept. of Interior, U.S. Geol. Survey, USGS open-file report 93-287, 1993.

Schouten, H., and K.D. Klitgord, The memory of the accreting plate boun- 
dary and the continuity of fracture zones, Earth Planet. Sci. Lett. 59, 255-266, 1982.

Schouten, H., S.C. Cande, and K.D. Klitgord, Magnetic anomaly profile south $\left(22^{\circ} \mathrm{N}\right.$ to $\left.28^{\circ} \mathrm{N}\right)$, in Mid-Atlantic Ridge Between $22^{\circ} \mathrm{N}$ and $38^{\circ} \mathrm{N}$, Mar. Sci. Int., Woods Hole, Mass., 1985 a.

Schouten, H., K.D. Klitgord, and J.A. Whitehead, Segmentation of midocean ridges, Nature, $317,225-229,1985 \mathrm{~b}$.

Schulz, N.J., R.S. Detrick, and S.P. Miller, Two and three-dimensional inversions of magnetic anomalies in the MARK area (Mid-Atlantic Ridge $\left.23^{\circ} \mathrm{N}\right)$, Mar. Geophys. Res., 10, 41-57, 1988.

Schwiderski, E.W., Ocean tides, Part II : a hydrodynamical interpolation model, Mar. Geod., 3, 219-255, 1980.

Searle, R.C., and A.S. Laughton. Sonar studies of the Mid-Atlantic Ridge and Kurchatov Fracture Zone, J. Geophys. Res., 82, 5313-5328, 1977.

Sempere, J.C., J. Lin, H.S. Brown, H. Schouten, and G.M. Purdy, Segmentation and morphotectonic variations along a slow-spreading center: The Mid-Atlantic Ridge $\left(24^{\circ} \mathrm{N}-30^{\circ} 40^{\prime} \mathrm{N}\right)$, Mar. Geophys. Res., 15 , 153-200, 1993.

Severinghaus, J.P., and K.C. Macdonald, High inside corners at ridgetransform intersections, Mar. Geophys. Res., 9, 353-367, 1988.

Shipboard Scientific Party, Site 395: 23N, Mid-Atlantic Ridge, Initial Rep. Deep Sea Drill. Proj., 45, 131-264, 1979.

Shipboard Scientific Party, Site 670, Proc. Ocean Drill. Program, Initial Rep., 109, 203-237, 1988.

Shipboard Scientific Party, Sites 920-924, Proc. Ocean Drill. Program, Initial Rep., 153, 45-272, 1995.

Sinha, M.C., D.A. Navin, L. M. Mac Gregor, S. Constable, C. Pierce, A. White, G. Heinson and M.A. Inglis, Evidence for accumulated melt beneath the slow-spreading Mid-Atlantic Ridge, Philos. Trans. $R$. Acad, London, 355, 233-253, 1997.

Sleep, N.H., Sensitivity of heat flow and gravity to the mechanism of seafloor spreading, J. Geophys. Res., 74, 542-549, 1969.

Sloan, H., and P. Patriat, Kinematics of the North American-African plate boundary between $28^{\circ}$ and $29^{\circ} \mathrm{N}$ during the last $10 \mathrm{Ma}$ : Evolution of the axial geometry and spreading rate and direction, Earth Planet. Sci. Lett. 113, 323-341, 1992.

Sparks, D.W., E.M. Parmentier, and J. Phipps Morgan, Three-dimensional mantle convection beneath a segmented spreading center: Implications for along-axis variations in crustal thickness and gravity, J. Geophys. Res., 98, 21,977-21,995, 1993.

Spector, A., and F.S. Grant, Statistical models for interpreting aeromagnetic data, Geophysics, 35(2), 293-302, 1970.

Stevenson, J.M., and J.A. Hildebrand, Gravity modeling of a volcanically active site on the East Pacific Rise axis, Tectonophysics, 254, 57-68, 1996.

Stevenson, J.M., J.A. Hildebrand, M.A. Zumberge and C. G. Fox, An ocean bottom gravity study of the southern Juan de Fuca Ridge, J. Geophys. Res., 99, 4875-4888, 1994.

Tapponnier, P., and J. Francheteau, Necking of the lithosphere and the mechanics of slowly accreting plate boundaries, J. Geophys. Res., 83, 3955-3970, 1978.
Tarantola, A., and B. Valette, Generalized nonlinear inverse problems solved using the least squares criterion, Rev. Geophys., 20, 219-232, $1982 a$.

Tarantola, A., and B. Valette, Inverse problerns: Quest for information, $J$. Geophys., 50, 159-170, 1982b.

Tolstoy, M., A.J. Harding, and J.A. Orcutt, Crustal thickness on the MidAtlantic Ridge: Bull's eye gravity anomalies and focused accretion, Science, 262, 726-729, 1993.

Tucholke, B.E., and J. Lin, Detachment faulting and its relation to geologic structure at first- and second-order offsets of slow-spreading ridges (abstract), Eos Trans. AGU, 73 (14), Spring Meet. Suppl., 286, 1992.

Tucholke, B.E., and J. Lin, A geological model for the structure of ridge segments in slow spreading ocean crust, J. Geophys. Res., 99, 11,93711,958, 1994.

Van Andel, T.H., and C.O. Bowin, Mid-Atlantic Ridge between $22^{\circ}$ and $23^{\circ}$ North latitude and the tectonics of mid-ocean rises, J. Geophys. Res., 73, 1279-1298, 1968.

Vera, E., P. Buhl, J. Mutter, A.J. Harding, J. Orcutt, and R. Detrick, The structure of 0-0.2 Myr old oceanic crust at $9^{\circ} \mathrm{N}$ in the East Pacific Rise from expanded spread profiles, J. Geophys. Res., 95, 15,529-15,556, 1990.

Vogt, P.R., E.D. Schneider, and G.L. Johnson, The crust and upper mantle beneath the sea, in The Earth's Crust and Upper Mantle: Structure, Dynamic Processes, and Their Relation to Deep-Seated Geological Phenomena, edited by P.J. Hart, pp. 556-617, AGU, Washington, D.C., 1969.

Wessel, P., and W.H.F. Smith, Free software helps map and display data, Eos Trans AGU, 72, 441, 445-446, 1991.

Whitehead, J.A., H.J.B. Dick, and A. Schouten, A mechanism for magmatic accretion under spreading centres, Nature, 312, 146-148, 1984.

Zonenshain, L.P., M.I. Kusmin, A.P. Lisitsin, Y.A. Bogdanov, and B.V. Baranov, Tectonics of the Mid-Atlantic rift valley between the TAG and MARK areas $\left(26-24^{\circ} \mathrm{N}\right)$ : Evidence for vertical tectonism, Tectonophysics, 159, 1-23, 1989.

V. Ballu, Marine Physical Laboratory, Scripps Institution of Oceanography, 9500 Gilman Drive, La Jolla, CA 92093-0205. (e-mail: valerie@mpl.ucsd.edu)

S. Bonvalot, C. Deplus, M. Diament, and J. Dubois, Laboratoire de Gravimétrie et Géodynamique, Institut de Physique du Globe de Paris, Case 89, 4 place Jussieu, 75252 Paris cedex 05, France. (e-mail: bonvalot@orstom.fr; deplus@ipgp.jussieu.fr; diament@ipgp.jussieu.fr; dubois@ipgp.jussieu.fr)

(Received January 29, 1997; revised August 29, 1997; accepted September 5, 1997.) 